\title{
ГЕОХИМИЯ РАССОЛОВ И НЕФТЕПРОЯВЛЕНИЙ КИМБЕРЛИТОВОЙ ТРУБКИ УДАЧНАЯ (СИБИРСКАЯ ПЛАТФОРМА)
}

Новиков Д. А., Ильин А. В., Каширцев В. А., Черных А. В., Пыряев А. Н., Дульцев Ф. Ф., Максимова А. А., Зуева И. Н., Чалая О. Н.

\section{Аннотация}

Приводятся результаты изучения геохимии рассолов и нефтепроявлений кимберлитовой трубки Удачная. Месторождение алмазов, как и все интрузивные тела Далдыно-Алакитского алмазоносного райо-на, является своеобразной криогидрогеологической микроструктурой, имеющей отличия от вмещающих осадочных пород, а также других алмазных трубок Якутской алмазоносной провинции. До разведанных глубин на месторождении в разрезе рудных тел выделяются две обводненные зоны, которые соотносятся с верхне- и среднекембрийскими водоносными комплексами. В пределах рудных тел и вмещающих пород распространены преимущественно кислые рассолы (средние величины $\mathrm{pH}=5,5$ ) с величиной общей минерализации от 94,3 до 391,3 г/дм3 Cl Ca и Cl Ca-Na состава. C глубиной происходит рост общей минерализа-ции и содержаний основных солеобразующих компонентов до горизонта -365 (абс. м), где она достигает 391 г/дм3, ниже наблюдается инверсия гидрогеохимического поля, где на горизонте -650 (абс. м) ее величина составляет 253 г/дм3. Минерализация $\mathrm{Cl} \mathrm{Ca}, \mathrm{Cl} \mathrm{Ca}-\mathrm{Na}, \mathrm{Cl} \mathrm{Ca}-$ $\mathrm{Mg}$ и $\mathrm{Cl} \mathrm{Ca}-\mathrm{Mg}-\mathrm{Na}$ рассолов верхнекембрийско-го комплекса изменяется в пределах от 102,9 до 192,9 г/дм3, а значения $\mathrm{pH}$ - от 4,9 до 6,2, составляя в сред-нем 5,6. Среди микрокомпонентов наиболее высокие средние концентрации установлены у (мг/дм3): Br1292,8 > S875,7 > Sr453,7 > Fe79,7 > Li53,4 > B32,7 > I13,3 > Si10,8 > Mn6,4 > Se3,6 > Rb2,3. Значения генетических коэффициентов ва-рьируют в широком интервале. Так, $\mathrm{rNa} / \mathrm{rCl}$ коэффициент колеблется от 0,18 до 0,$31 ; \mathrm{rCa} / \mathrm{rMg}$ от 1,03 до 3,6; $\mathrm{Ca} / \mathrm{Cl}$ от 0,2 до 0,3, а интегрированный показатель метаморфизации (по С.Л. Шварцеву) S изменяется от 193 до 277. Среднекембрийский комплекс содержит более минерализованные рассолы и значительно шире оха-рактеризован фактическим материалом. В нем распространены рассолы Cl Ca, Cl Ca-Na, Cl Ca-Mg и Cl Na-Mg состава с величиной общей минерализации от 94,3 до 391,3 г/дм3. В рассолах высокими средними кон-центрациями характеризуются следующие микрокомпоненты (мг/дм3): Br2224,9 > Sr1024,9 >S500,1 > B202,9 > Li147,1 > Fe97,0 > I33,2 > Rb11,4 > Si9,6 > Se9,5 > Mn3,6 > Ni1,7. В сравнении с вышезалегающими, среднекембрийские рассолы отличаются более широкой вариацией отношения $\mathrm{rNa} / \mathrm{rCl}$ от 0,14 до 0,34; rCa/rMg от 0,66 до 9,71; Ca/Cl от 0,03 до 0,45. Степень метаморфизации рассолов также значительно выше, что отмечается не только по от-ношениям $\mathrm{rNa} / \mathrm{rCl}$ и rCa/rMg, но и по показателю S, который изменяется в интервале от 278 до 316.

Изучен состав стабильных изотопов $\delta \mathrm{D}$ и $\delta 18 \mathrm{O}$ рассолов и растворенного в них неорганического уг-лерода $\delta 13 C$. Предполагается седиментационно-метаморфический генезис изученных вод. Их изотопный состав отражает климатические условия времени захоронения с вероятным вкладом изотопного обмена кислородом с водовмещающими породами. Значения отношения $\delta 13 \mathrm{C}$ растворенной в водах углекислоты позволяет сделать вывод о ее биогенном происхождении. Механизм биогенного изотопного обмена углеро-да определяется соотношением метаногенных и SMT-процессов. Проведенный анализ изотопных отноше-ний $87 \mathrm{Rb} / 86 \mathrm{Sr}$ и $87 \mathrm{Sr} / 86 \mathrm{Sr}$ исследованных рассолов показал, что воды кембрийских отложений соответствуют изотопному составу древнего океана.

На масс-хроматограммах фракций насыщенных углеводородов (УВ) выделяются по крайней мере два индивидуальных типа нефтей и мальт. Третья разновидность представлена смешением первых двух в процессе разновременных этапов миграции, а четвертая - из зоны контакта, изменена при эксплозии ким-берлитов. Самым распространенным является первый «постэксплозивный» тип нафтидов, близкий по всем геохимическим параметрам к нефтям Непско-Ботуобинской антеклизы 
и, в частности, нефтям Мирнинского свода. Нефти второго (доэксплозионного) типа приурочены лишь к удачнинской свите в интервале глубин 1130-1430 м.

\section{Ключевые слова:}

Гидрогеология, геохимия рассолов, геохимия нефтепроявлений, степень метаморфизации, стабильные изотопы, нефтегазоносност, кимберлитовая трубка Удачная, Сибирская платформа, Арктика 


\title{
ГЕОХИМИЯ РАССОЛОВ И НЕФТЕПРОЯВЛЕНИЙ КИМБЕРЛИТОВОЙ ТРУБКИ
}

\author{
УДАЧНАЯ (СИБИРСКАЯ ПЛАТФОРМА)
}

\author{
(C) 2020 г. Д.А. Новиков ${ }^{1,2 *}$, А.В. Ильин ${ }^{3}$, В.А. Каширцев ${ }^{1,2}$, А.В. Черных ${ }^{1}$, \\ А.Н. Пыряев ${ }^{2,4}$, Ф.Ф. Дульцев ${ }^{1}$, Максимова А.А. ${ }^{1}$, Зуева И.Н. ${ }^{5}$, Чалая О.Н. \\ ${ }^{1}$ Институт нефтегазовой геологии и геофизики им. А.А. Трофимука СО РАН \\ Россия, 630090 Новосибирск, проспект Академика Коптюга, 3 \\ ${ }^{2}$ Новосибирский национальный исследовательский государственный университет \\ Россия, 630090 Новосибирск, ул. Пирогова, 1 \\ ${ }^{3}$ Вилюйская геологоразведочная экспедиция АК "АЛРОСА" (ПАО) \\ Россия, 678170, г. Мирный \\ ${ }^{4}$ Институт геологии и минералогии им. В.С. Соболева СО РАН \\ Россия, 630090 Новосибирск, проспект Академика Коптюга, 3 \\ ${ }^{5}$ Институт проблем нефти и газа СО РАН \\ Россия, 677890 Якутск, ул. Октябрьская, 1 \\ *E-mail: NovikovDA@ipgg.sbras.ru
}

\begin{abstract}
Приводятся результаты изучения геохимии рассолов и нефтепроявлений кимберлитовой трубки Удачная. Месторождение алмазов, как и все интрузивные тела Далдыно-Алакитского алмазоносного района, является своеобразной криогидрогеологической микроструктурой, имеющей отличия от вмещающих осадочных пород, а также других алмазных трубок Якутской алмазоносной провинции. До разведанных глубин на месторождении в разрезе рудных тел выделяются две обводненные зоны, которые соотносятся с верхне- и среднекембрийскими водоносными комплексами. В пределах рудных тел и вмещающих пород распространены преимущественно кислые рассолы (средние величины $\mathrm{pH}=5,5$ ) с величиной общей минерализации от 94,3 до 391,3 г/дм ${ }^{3} \mathrm{Cl}$ Ca и $\mathrm{Cl}$ Ca-Na состава. C глубиной происходит рост общей минерализации и содержаний основных солеобразующих компонентов до горизонта -365 (абс. м), где она достигает 391 г/дм ${ }^{3}$, ниже наблюдается инверсия гидрогеохимического поля, где на горизонте -650 (абс. м) ее величина составляет 253 г/дм³. Минерализация $\mathrm{Cl} \mathrm{Ca}$, Cl Ca-Na, Cl Ca-Mg и Cl Ca-Mg-Na рассолов верхнекембрийского комплекса изменяется в пределах от 102,9 до 192,9 г/дм³ , а значения рН - от 4,9 до 6,2, составляя в среднем 5,6. Среди микрокомпонентов наиболее высокие средние концентрации установлены у $\left(\right.$ мг/дм $\left.{ }^{3}\right): \mathrm{Br}_{1292,8}>\mathrm{S}_{875,7}>\mathrm{Sr}_{453,7}>\mathrm{Fe}_{79,7}>\mathrm{Li}_{53,4}>\mathrm{B}_{32,7}>\mathrm{I}_{13,3}>\mathrm{Si}_{10,8}>\mathrm{Mn}_{6,4}>\mathrm{Se}_{3,6}>\mathrm{Rb}_{2,3}$. Значения генетических коэффициентов варьируют в широком интервале. Так, $\mathrm{rNa} / \mathrm{rCl}$ коэффициент колеблется от 0,18 до 0,31; $\mathrm{rCa} / \mathrm{rMg}$ от 1,03 до 3,6; $\mathrm{Ca} / \mathrm{Cl}$ от 0,2 до 0,3, а интегрированный показатель метаморфизации (по С.Л. Шварцеву) S изменяется от 193 до 277. Среднекембрийский комплекс содержит более минерализованные рассолы и значительно шире охарактеризован фактическим материалом. В нем распространены рассолы Cl Ca, Cl Ca-Na, Cl Ca-Mg и Cl Na-Mg состава с величиной общей минерализации от 94,3 до 391,3 г/дм³. В рассолах высокими средними концентрациями характеризуются следующие микрокомпоненты (мг/дм $\left.{ }^{3}\right): \mathrm{Br}_{2224,9}>\mathrm{Sr}_{1024,9}>\mathrm{S}_{500,1}>\mathrm{B}_{202,9}>\mathrm{Li}_{147,1}>\mathrm{Fe}_{97,0}>\mathrm{I}_{33,2}>\mathrm{Rb}_{11,4}>\mathrm{Si}_{9,6}>\mathrm{Se}_{9,5}>\mathrm{Mn}_{3,6}>$ $\mathrm{Ni}_{1,7}$. В сравнении с вышезалегающими, среднекембрийские рассолы отличаются более широкой вариацией отношения $\mathrm{rNa} / \mathrm{rCl}$ от 0,14 до 0,$34 ; \mathrm{rCa} / \mathrm{rMg}$ от 0,66 до 9,71; $\mathrm{Ca} / \mathrm{Cl}$ от 0,03 до 0,45. Степень метаморфизации рассолов также значительно выше, что отмечается не только по отношениям $\mathrm{rNa} / \mathrm{rCl}$ и $\mathrm{rCa} / \mathrm{rMg}$, но и по показателю S, который изменяется в интервале от 278 до 316.

Изучен состав стабильных изотопов $\delta \mathrm{D}$ и $\delta^{18} \mathrm{O}$ рассолов и растворенного в них неорганического углерода $\delta^{13} \mathrm{C}$. Предполагается седиментационно-метаморфический генезис изученных вод. Их изотопный состав отражает климатические условия времени захоронения с вероятным вкладом изотопного обмена кислородом с водовмещающими породами. Значения отношения $\delta^{13} \mathrm{C}$ растворенной в водах углекислоты позволяет сделать вывод о ее биогенном происхождении. Механизм биогенного изотопного обмена углерода определяется соотношением метаногенных и SMT-процессов. Проведенный анализ изотопных отношений ${ }^{87} \mathrm{Rb} /{ }^{86} \mathrm{Sr}$ и ${ }^{87} \mathrm{Sr} /{ }^{86} \mathrm{Sr}$ исследованных рассолов показал, что воды кембрийских отложений соответствуют изотопному составу древнего океана.

На масс-хроматограммах фракций насыщенных углеводородов (УВ) выделяются по крайней мере два индивидуальных типа нефтей и мальт. Третья разновидность представлена смешением первых двух в
\end{abstract}


процессе разновременных этапов миграции, а четвертая - из зоны контакта, изменена при эксплозии кимберлитов. Самым распространенным является первый «постэксплозивный» тип нафтидов, близкий по всем геохимическим параметрам к нефтям Непско-Ботуобинской антеклизы и, в частности, нефтям Мирнинского свода. Нефти второго (доэксплозионного) типа приурочены лишь к удачнинской свите в интервале глубин 1130-1430 м.

Гидрогеология, геохимия рассолов, геохимия нефтепроявлений, степень метаморфизации, стабильные изотопы, нефтегазоносность, кимберлитовая трубка Удачная, Сибирская платформа, Арктика.

\section{ВВЕДЕНИЕ}

В настоящее время Россия занимает первое место в мире по запасам алмазов и их добыче. Государственным балансом запасы алмазов на территории Российской Федерации учтены по 79 месторождениям, в том числе по 25 коренным (23 кимберлитовым и 2 импактным) и 54 россыпным [Иванов и др., 2016].

Кимберлитовая трубка Удачная (рис. 1) расположена на левом берегу ручья Пиропового - правого притока р. Далдын (приток р. Марха, которая впадает в р. Вилюй). Это крупнейшее по размерам рудного тела месторождение алмазов в России находится в 20 км от Северного полярного круга в Якутской алмазоносной провинции. Открытая разработка осуществлялась с 1971 г. до июня 2014 г., глубина карьера достигла 640 м (рис. 2), а в настоящее время добыча алмазов продолжается подземным способом. Как в карьере, так и в подземном руднике отработка месторождения осложнена притоком хлоридных подземных рассолов в шахту на глубине свыше 700 м (-365...-465 м абс.) [Алексеев и др., 2018]. Строительство подземного рудника вскрыло ряд негативных особенностей месторождения, при этом наибольшие проблемы проявились при вскрытии водо- и нефтегазонасыщенных зон. Во всех подземных сооружениях начались возгорания нефтепроявлений, взрывы газовоздушных смесей при шпуровой отпалке горной массы. Некоторые аварии и инциденты привели к вынужденным простоям и значительным материальным затратам [Дроздов, Мельников, 2015].

Планомерное геологическое изучение исследуемого района было начато в начале 50-х годов прошлого века. В 1953 году в бассейне р. Далдын Северной экспедицией Иркутского геологического управления была проведена геологическая съемка масштаба 
1:1000000, результатом которой явилось обнаружение в аллювии р. Далдын пиропов и алмазов. В 1953-1954 гг. в районе проводились маршрутные и тематические работы на алмазы. В 1954 г на левобережье р. Далдын Л.А. Попугаева открыла первую в СССР кимберлитовую трубку Зарница, что выдвинуло бассейн р. Далдын в число наиболее перспективных площадей для поисков месторождений алмазов. В 1954-1955 гг. территория исследуемого района была покрыта кондиционной геологической съемкой масштаба 1:200000, в результате которой была установлена алмазоносность русловых отложений р. Далдын. При этом в 1955 г была открыта кимберлитовая трубка Удачная. В настоящее время вся площадь исследуемого района полностью покрыта геологической съемкой масштаба 1:50000.

В гидрогеологическом отношении изучаемая территория закартирована комплексными гидрогеологическими и мерзлотно-геологическими съемками масштабов 1:50000 и 1:200000. По результатам съемки 1979-1983 гг., проведенной Айхальской экспедицией, были выделены водоносные комплексы и дана оценка их фильтрационных параметров [Павлов, 1983]. По данным комплексной гидрогеологической съемки масштаба 1:200000 (1979, 1984, 1988 гг.) были установлены региональные границы распространения водоносных комплексов, гидрогеологическая и гидрогеохимическая зональность, а также интенсивность развития современных криогенных процессов и явлений [Лазебник, 1988].

Результаты гидрогеологических и геокриологических исследований кимберлитовой трубки Удачная отражены в работах З.Г. Устиновой, И.В. Климовского, А.В. Дроздова, В.Т. Балобаева, К.Н. Егорова, С.В. Алексеева, Л.П. Алексеевой, В.Н. Борисова, И.Н. Александрова, Я.Б. Легостаевой и многих других [Устинова, 1964; Балобаев, Девяткин, 1983; Дроздов и др., 1989; Климовский, Готовцев, 1994; Александров и др., 2003; Дроздов, 2005; Алексеев и др., 2007; Алексеев, 2009; Атрощенко, 2012; Легостаева и др., 2018; Алексеева, Алексеев, 2019]. В настоящем исследовании впервые выполнен 
комплексный анализ архивных и новых материалов 2019 года по геохимии подземных рассолов и нефтепроявлений кимберлитовой трубки Удачная.

\section{МАТЕРИАЛЫ И МЕТОДЫ ИССЛЕДОВАНИЙ}

В период с марта по июнь 2019 года в соответствии с общепринятыми методиками выполнено опробование подземных рассолов и нефтепроявлений в пределах кимберлитовой трубки Удачная. Лабораторное изучение химического состава методами титриметрии, ионной хроматографии, масс-спектрометрии с индуктивно связанной плазмой (ИСП), проводилось в Проблемной научно-исследовательской лаборатории гидрогеохимии Инженерной школы природных ресурсов Национального исследовательского Томского политехнического университета (аналитики О.В. Чеботарева, Н.В. Бублий, А.С. Погуца, В.В. Куровская, К.Б. Кривцова, Л.А. Ракул).

Анализ комплекса изотопных отношений $\delta \mathrm{D}, \delta^{18} \mathrm{O}, \delta^{13} \mathrm{C}_{\mathrm{DIC}}$ вод и растворенного неорганического углерода (Dissolved Inorganic Carbon (DIC)) проводился в центре коллективного пользования Института геологии и минералогии им. В.С. Соболева СО РАН с помощью прибора Isotope Ratio Mass Spectrometer Finnigan ${ }^{\mathrm{TM}}$ MAT 253, снабженного приставками пробоподготовки H/Device (для анализа отношений $\delta \mathrm{D}$ ) и GasBench II (для анализа отношений $\delta^{18} \mathrm{O}$ и $\left.\delta^{13} \mathrm{C}_{\mathrm{DIC}}\right)$. Изотопные отношения $\delta^{13} \mathrm{C}_{\mathrm{DIC}}, \delta \mathrm{D}$ и $\delta^{18} \mathrm{O}$ измерялись относительно мировых стандартов: VSMOW2; SLAP2; GISP - для анализа изотопных отношений водорода и кислорода; NBS-18; NBS-19 - для анализа $\delta^{13} C_{\text {DIC. }}$ Ошибка определения изотопного состава стандартов по углероду и кислороду - не более 0,1 \%о, по водороду - не более 2 \%. Изотопные отношения ${ }^{87} \mathrm{Sr}^{86} / \mathrm{Sr}$ и ${ }^{87} \mathrm{Rb} /{ }^{86} \mathrm{Sr}$ изучались на массспектрометре MI 1201T в двухленточном режиме с регистрацией на одном коллекторе. Погрешность определения отношений ${ }^{87} \mathrm{Rb} /{ }^{86} \mathrm{Sr}$ не превышает $1 \%$.

В хлороформных экстрактах после осаждения асфальтенов избытком петролейного эфира мальтеновую часть на хроматографических колонках с силикагелем АСК + окись алюминия разделяли на метановонафтеновые и нафтеновоароматические углеводороды, 
бензольные и спиртобензольные смолы. Границы между фракциями определялись по показателю рефракции и свечению в ультрафиолетовом излучении.

Хромато-масс-спектрометрические исследования насыщенных углеводородов проводились на системе, включающей газовый хроматограф 6890, имеющий интерфейс с высокоэффективным масс-селективным детектором Agilent 5973N. Хроматограф снабжен кварцевой капиллярной колонкой длиной 30 м диаметром 0.25 мм, импрегнированной фазой HP-5MS. В качестве газа-носителя служил гелий со скоростью потока 3 мл/мин. Температура испарителя $320^{\circ} \mathrm{C}$. Ввод пробы при $100^{\circ} \mathrm{C}$. Изотермическая "площадка" длительностью 4 мин. Программирование подъема температуры осуществлялось от $100^{\circ} \mathrm{C}$ до $290^{\circ} \mathrm{C}$ со скоростью $4^{\circ} \mathrm{C} /$ мин с последующей изотермой в течение 30 мин. Ионизирующее напряжение источника- $70 \mathrm{eV}$, температура источника - $250^{\circ} \mathrm{C}$. Хроматограммы углеводородов были получены по общему ионному току (ПС) и селективным ионам (показаны на рисунках). Идентификация соединений проводилась с использованием библиотеки масс-спектров NIST05.

Помимо новых были обобщены архивные материалы гидрогеохимических исследований рудных тел и водосборников трубки Удачная. Электронная база данных включает данные по 85 пробам подземных рассолов, 24 пробам водорастворенных газов (ВРГ) и 82 хлороформным экстрактам (холодная экстракция) из нефте- и битумонасыщенного керна скважин КСС-1, 2 и 3 и проб, отобранных в зоне контакта кимберлитов и вмещающих пород (карьер).

\section{РЕЗУЛЬТАТЫ И ИХ ОБСУЖДЕНИЕ}

\section{Гидрогеологические условия}

Гидрогеологическая изученность Далдыно-Алакитского алмазоносного района в целом и района трубки Удачная в частности, довольно высокая в связи с развитием здесь алмазопоисковых работ и промышленным освоением коренных месторождений алмазов (трубок Удачная, Сытыканская, Зарница и другие). Кимберлитовая трубка Удачная, как и 
все интрузивные тела в регионе, является своеобразной криогидрогеологической микроструктурой, имеющей отличия от вмещающих осадочных пород, а также других алмазных трубок провинции. До разведанных глубин на месторождении в разрезе рудных тел выделяются две обводненные зоны, которые соотносятся с верхне- и среднекембрийскими водоносными комплексами (рис. 3). Водоносные зоны изучены достаточно детально до глубины 550 м (-200 абс. м), а ниже - до глубины 1430 м (-1080 абс. м) - гидрогеологические исследования проводились в процессе бурения разведочных и эксплуатационно-разведочных скважин.

Фильтрационные параметры кимберлитов довольно изменчивы, водопроводимость варьируется от 1-2 до 70 м²/сут, и всегда превышают аналогичные показатели вмещающих пород. Пьезометрический уровень водоносных зон устанавливался на тех же отметках, что и уровень верхнекембрийского водоносного комплекса. По данным опытнофильтрационных работ не было выявлено прямой гидравлической связи между первыми водоносными зонами рудных тел, хотя общая продолжительность опытных откачек достигала нескольких месяцев. В то же время существует затрудненная связь между обводненными зонами рудных тел и водонасыщенными породами вмещающих осадочных толщ.

Водонасыщенные кимберлиты рудных тел различаются по глубинам распространения, фильтрационным параметрам и химическому составу рассолов. Водонасыщенная зона западного тела по фильтрационным свойствам характеризуется малой водообильностью и низкими значениями гидродинамических параметров. Коэффициент водопроводимости составляет 2-5 м²/сут.

Рудные кимберлитовые тела непосредственно контактируют с водовмещающими коллекторами среднекембрийского водоносного комплекса, и поэтому водообильность кимберлитов полностью зависит от соответствующих параметров его интервалов. Пьезометрический уровень второй обводненной зоны имеет единую поверхность с 
пьезометрическим уровнем среднекембрийского водоносного комплекса. Многолетние наблюдения за уровенным режимом нижних интервалов среднекембрийского водоносного комплекса показали планомерное снижение пьезометрических уровней в скважинах при общем 400-метровом водопонижении в центре карьерного поля.

\section{Ионно-солевой состав рассолов}

В пределах рудных тел и вмещающих пород распространены преимущественно кислые рассолы (средние величины $\mathrm{pH}=5,5$ ) с величиной общей минерализации от 94,3 до 391,3 г/дм³ хлоридного кальциевого и кальциево-натриевого состава. С глубиной происходит рост общей минерализации и содержаний основных солеобразующих компонентов до горизонта -365 (абс. м), где она достигает 391 г/дм³, ниже наблюдается инверсия гидрогеохимического разреза и на горизонте -650 (абс. м) ее величина не превышает 253 г/дм ${ }^{3}$ Среди катионов и анионов преобладают $\mathrm{Na}^{+}, \mathrm{Ca}^{2+}$ и $\mathrm{Cl}^{-}$, достигая 40,5, 109,0 и 258,8 г/дм³ соответственно. Остальные макрокомпоненты не превышают: $\mathrm{Mg}^{2+}-19,4 ; \mathrm{K}^{+}-17,1 ; \mathrm{SO}_{4}{ }^{2-}-4,4$ и $\mathrm{HCO}_{3}{ }^{-}-2,1$ г/дм ${ }^{3}$.

Минерализация $\mathrm{Cl}$ Ca, $\mathrm{Cl}$ Ca-Na, Cl Ca-Mg и $\mathrm{Cl}$ Ca-Mg-Na рассолов верхнекембрийского водоносного комплекса изменяется в пределах от 102,9 до 192,9 г/дм³, а значения $\mathrm{pH}$ - от 4,9 до 6,2, составляя в среднем 5,6. Значения генетических коэффициентов варьируют в широком интервале. Так, $\mathrm{rNa} / \mathrm{rCl}$ коэффициент колеблется от 0,18 до 0,31; rCa/rMg от 1,03 до 3,6; Ca/Cl от 0,2 до 0,3, а интегрированный показатель метаморфизации (по С.Л. Шварцеву) [Шварцев, 2000] S варьирует от 193 до 277.

Среднекембрийский водоносный комплекс содержит более минерализованные рассолы и значительно шире охарактеризован фактическим материалом. В нем распространены рассолы $\mathrm{Cl} \mathrm{Ca}, \mathrm{Cl} \mathrm{Ca}-\mathrm{Na}, \mathrm{Cl} \mathrm{Ca}-\mathrm{Mg}$ и $\mathrm{Cl}$ Na-Mg химических типов с величиной общей минерализации от 94,3 до 391,3 г/дм³ (рис. 4, табл. 1).

Рассмотрим подробнее общие черты подземных рассолов среднекембрийского водоносного комплекса по основным горизонтам отработки рудных тел. Рассолы 
горизонта -320 (абс. м) западного рудного тела (ЗРТ) имеют $\mathrm{Cl}$ Са состав, значения $\mathrm{pH}$ составляют 4-5 (среднее 4,6), а величина их общей минерализации изменяется в узком интервале - от 344,2 до 355,2 г/дм³ . Минерализация рассолов Cl Ca и Cl Ca-Na составов восточного рудного тела (ВРТ) охватывает больший диапазон - от 335,5 до 378,5 г/дм³, при $\mathrm{pH}$ от 4,5 до 5, в среднем составляя 4,6. Горизонт -365 (абс. м) характеризуется распространением Cl Ca и Cl Ca-Na рассолов с минерализацией от 182,1 до 391,3 г/дм³, значениями рН от 4,0 до 6,5 (среднее 4,7). Среди подземных рассолов ЗРТ этого горизонта распространены Cl Ca и Cl Ca-Na типы с величиной общей минерализации 273,1-391,3 г/дм ${ }^{3}$ и рН от 4,0 до 6,5 (среднее - 4,7). Рассолы ВРТ отличаются более низкой минерализацией $(258,8$ - 377,2 г/дм³) при таком же химическом составе и более кислыми значениями $\mathrm{pH}$ с величинами от 4,0 до 5,5. Рассолы горизонта -380 (абс. м) преимущественно Cl Ca и Cl Ca-Na состава, с более высокой минерализацией от 295,2 до 344,5 г/дм³ и кислыми рН - от 4,0 до 5,0, при среднем 4,8. В горизонте -465 (абс. м) доминируют $\mathrm{Cl}$ Са рассолы с минерализацией от 372,6 до 391,3 г/дм³ и рН от 4,6 до 4,9 (среднее 4,7). Рассолы горизонта -480 (абс. м) имеют $\mathrm{Cl}$ Ca и $\mathrm{Cl} \mathrm{Ca}-\mathrm{Na}$ состав, с значениями $\mathrm{pH}$ изменяющимися от 4,0 до 5,5 (при среднем 4,8), и величиной общей минерализации от 357,8 до 362,4 г/дм³. Величина общей минерализации $\mathrm{Cl} \mathrm{Ca}, \mathrm{Cl} \mathrm{Ca}-\mathrm{Na}$ и Cl Ca-Mg рассолов в горизонте -580 (абс. м) изменяется от 153,1 до 323,7 г/дм³ варьирует от 4,0 до 7,0, в среднем составляя 5,0. Самый глубокий из изученных горизонт -650 (абс. м) характеризуется рассолами $\mathrm{Cl}$ Са состава с минерализацией от 94,4 до 253,3 г/дм³, и рН от 5 до 6 (среднее 5,4).

В сравнении с вышезалегающими верхнекембрийскими, среднекембрийские рассолы отличаются более широкой вариацией отношения $\mathrm{rNa} / \mathrm{rCl}$ от 0,14 до 0,34; rCa/rMg от 0,66 до 9,71; $\mathrm{Ca} / \mathrm{Cl}$ от 0,03 до 0,45. Степень метаморфизации рассолов также значительно выше, что отмечается не только по отношениям $\mathrm{rNa} / \mathrm{rCl}$ и $\mathrm{rCa} / \mathrm{rMg}$, но и по интегрированному показателю метаморфизации S, который составляет от 278 до 316. В 
целом, подземные рассолы кимберлитовых трубок исследуемого района (Удачная, Айхал, Заполярная, Поисковая и других) характеризуются средней степенью метаморфизации химического состава и несут геохимические черты проявления процессов криогенного метаморфизма, что требует дальнейших исследований. Так, рассолы трубки Мир характеризуются наибольшей степенью метаморфизации химического состава среди изученных и достигают стадии садки сильвина. $\mathrm{Ca} / \mathrm{Cl}$ отношение составляет 0,55-0,63, тогда как в рассолах трубки Удачная оно не превышает 0,45. Большинство рассолов трубок Айхал, Заполярная, Поисковая, Новинка, Осенняя и Зарница не достигают стадии садки гипса, а величина их общей минерализации не превышает 150 г/дм³ [Novikov, 2017; Каширцев и др., 2019].

\section{Микрокомпонентный состав рассолов}

Изученные рассолы имеют интересный спектр распределения микрокомпонентов. Некоторые результаты предыдущих исследований приведены нами ранее [Новиков и др., 2020]. Средние концентрации изученных элементов в рассолах верхнекембрийского и среднекембрийского водоносных комплексов трубки Удачная, а также рассолов трубки Нюрбинская приведены на рисунке 5. В верхнекембрийском водоносном комплексе наиболее высокие средние содержания установлены у (мг/дм³): $\mathrm{Br}_{1292,8}>\mathrm{S}_{875,7}>\mathrm{Sr}_{453,7}>$ $\mathrm{Fe}_{79,7}>\mathrm{Li}_{53,4}>\mathrm{B}_{32,7}>\mathrm{I}_{13,3}>\mathrm{Si}_{10,8}>\mathrm{Mn}_{6,4}>\mathrm{Se}_{3,6}>\mathrm{Rb}_{2,3}$. Содержания Zn, Ва и $\mathrm{P}$ не превышают 0,8 мг/дм³ , а остальных микрокомпонентов - 0,09 мг/дм³ . В рассолах среднекембрийского водоносного комплекса высокими средними концентрациями характеризуются практически те же элементы при более высоких концентрациях (мг/дм³): $\mathrm{Br}_{2224,9}>\mathrm{Sr}_{1024,9}$ $>\mathrm{S}_{500,1}>\mathrm{B}_{202,9}>\mathrm{Li}_{147,1}>\mathrm{Fe}_{97,0}>\mathrm{I}_{33,2}>\mathrm{Rb}_{11,4}>\mathrm{Si}_{9,6}>\mathrm{Se}_{9,5}>\mathrm{Mn}_{3,6}>\mathrm{Ni}_{1,7}$. Содержания Ba, Cs, Ti, V, Co, Zn, Al, As, P варьируют от 0,1 до 0,4 мг/дм³ , а остальных элементов от 0,0001 до 0,06 мг/дм³ Характер распределения микрокомпонентов в рассолах трубки Нюрбинская в большей степени схож с распределением в трубке Удачная. При этом, рассолы трубки 
Удачной в большей мере обогащены Li, Zn, Nb, Ag, In, Cs, Ta, W, Ir, Au, Hg и Bi и в меньшей Al, S, Mo, Cd и Re.

Для оценки степени концентрирования химических элементов в рассолах был рассчитан коэффициент концентрации, который отражает отношение их содержаний в рассоле к вмещающим породам или к кларку осадочного слоя литосферы, карбонатов и эвапоритов [Григорьев, 2010] (рис. 6). Практически по всем представленным микрокомпонентам распределение коэффициентов концентрирования в верхнекембрийском и среднекембрийском водоносных комплексах имеют схожий характер. Установлено, что относительно осадочного слоя во всех кембрийских рассолах концентрируются Li, B, Ti, Se, Br, Sr, I, Au и Hg. В верхнекембрийском комплексе коэффициент концентрирования также выше единицы у S, а в среднекембрийском - y Rb (рис. 6а). Относительно карбонатных пород в рассолах обоих комплексов концентрируются Li, B, Se, Br, Sr, Ag, I и Hg, а в среднекембрийском - Rb и Cs (рис. 6б). Относительно эвапоритов в кембрийских рассолах коэффициенты концентрирования выше единицы у Li, B, Mn, Fe, Se, Br, Sr и I, в среднекембрийском также выше единицы у $\mathrm{Rb}$, а в верхнекембрийском - у P (рис. 6в). Таким образом, в изученных рассолах в наибольшей степени концентрируются $\mathrm{Br}, \mathrm{Sr}, \mathrm{B}, \mathrm{Li}, \mathrm{I}, \mathrm{Si}, \mathrm{Mn}$ и Se. Вопросы фракционирования химических элементов в системе вода-порода требуют также детального изучения состава кимберлитов и вмещающих пород.

\section{Геохимия водорастворенных газов}

Подмерзлотные воды месторождения отличаются повсеместной газонасыщенностью, величина которой на различных горизонтах месторождения остаётся практически неизменной и колеблется от 0,15 до 0,3 л/л (рис. 7а), составляя до 0,9 л/л на глубине 750 м [Дроздов, Мельников, 2015]. По взаимоотношению компонентов ВРГ подразделяются на: азотные, углеводородно-азотные, азотно-углеводородные и углеводородные по классификации Л.М. Зорькина [Зорькин, 1973]. Газы азотного типа 
имеют наименьшее распространение и выявлены в верхнекембрийском водоносном комплексе только вблизи тектонических зон. Газонасыщенность подземных вод составляет 0,1-0,2 л/л. Газовая фаза представлена на 76-83 об.\% азотом, 14-21 \% метаном, 0,2-0,3 об.\% тяжелыми углеводородами; углекислого газа, гелия и водорода: 2,7-3,0; 0,03-0,06; 0,22-0,34 об.\%, соответственно. Углеводородно-азотные газы встречаются также ограниченно, лишь в верхнекембрийском водоносном комплексе. Содержание ВРГ в этих рассолах изменяется в пределах 0,11-0,15 л/л. В их составе: азота 51-62 об.\%, углеводородных газов 36-48 об.\%, тяжелых углеводородов 0,8-1,1 об.\%, углекислого газа 0,4 об.\%, водорода 0,47 об.\%, гелия 0,06-0,08 об.\%. Азотно-углеводородные газы распространены в рассолах верхнекембрийского водоносного комплекса при содержаниях 0,1-0,3 л/л. В их составе углеводородные газы достигают 65 об.\%, азот составляет 22-41 об.\%, углекислого газа до 2,3 об.\%, появляются тяжелые углеводороды (до 2,3 об.\%).

Наибольшее распространение в подземных водах месторождения имеют углеводородные газы. Начиная со второго горизонта верхнекембрийского комплекса (0... -35 абс. м) и ниже распространены рассолы величиной общей газонасыщенности до 1,1 л/л (среднее - 0,6 л/л). Доля метана в них составляет 75-85 об.\%, концентрации тяжелых углеводородов возрастают до 1,9-10, содержание азота снижается до 2-10, углекислого газа не более 2,8, водорода 0,1-1,2, гелия 0,2 об.\%. Сероводород по всему изученному разрезу до глубины 1400 м (гор. -1080 абс. м) не обнаружен.

Наиболее детально изучен состав ВРГ среднекембрийского водоносного комплекса горизонтов -320, -365 и -380 (абс. м) (табл. 2). Газы характеризуется метановым составом и относятся к углеводородному классу с содержанием $\mathrm{CH}_{4}$ от 62 до 79 об.\% (рис. 7б). Сумма углеводородов в составе ВРГ варьирует от 85 до 97 об.\%. Среди углеводородов содержания гомологов метана изменяются от 13 до 32 об.\%. Преобладающую роль играют этан и пропан, концентрации которых достигают 20 и 10 об.\% соответственно (рис. 7в). Содержания $\mathrm{N}_{2}$ изменяются от 2 до 15 и $\mathrm{CO}_{2}$ от 0,002 до 2,479 об.\% соответственно. 
Количество гелия и водорода незначительно (доли процентов). Для горизонта -320 (абс. м) характерно содержание $\mathrm{CH}_{4}$ от 62 до 79 об.\%, $\mathrm{C}_{2} \mathrm{H}_{6}$ от 12 до 20 об.\% и $\mathrm{C}_{3} \mathrm{H}_{8}$ от 4 до 9 об.\%. Концентрации $\mathrm{CO}_{2}$ и $\mathrm{N}_{2}$ в среднем составляют 1 и 3 об.\%. В ВРГ горизонта -365 (абс. м) содержания $\mathrm{CH}_{4}$ варьируют от 65 до 74 об.\%, $\mathrm{C}_{2} \mathrm{H}_{6}$ от 8 до 18 об.\% и $\mathrm{C}_{3} \mathrm{H}_{8}$ от 3 до 10 об.\%. В данном горизонте отмечаются наибольшие концентрации углекислого газа и азота средние содержания которых составляют 0,5 и 8 об.\% соответственно. ВРГ горизонта -380 (абс. м) представлены $\mathrm{CH}_{4} 78$ об.\%, $\mathrm{C}_{2} \mathrm{H}_{6} 11$ об.\% и $\mathrm{C}_{3} \mathrm{H}_{8} 5$ об.\%, здесь же выявлены наименьшие содержания $\mathrm{CO}_{2}$ и $\mathrm{N}_{2}$, которые в среднем равны 0,8 и 2,2 об.\%.

На рисунке 8 видно, что наибольший разброс содержаний наблюдается по углекислому газу, содержание которого варьируют от 0,002 до 2,479 об.\%. Средние значения для горизонтов -320, -365 и -380 (абс. м) равны 1, 0,5 и 0,8 об.\% соответственно. Минимальной вариабельностью характеризуется метан (от 62 до 79 об.\%), средние содержания которого по изученным горизонтам составляют 69, 70 и 78 об.\%. Отмечается закономерная тенденция снижения концентраций тяжелых углеводородов в ряду от этана до неопентана.

Изотопный состав рассолов $\left(\delta \mathrm{D}, \delta^{18} \mathrm{O}, \delta^{13} \mathrm{C},{ }^{87} \mathrm{Sr}^{86} / \mathrm{Sr},{ }^{87} \mathrm{Rb} /{ }^{86} \mathrm{Sr}\right)$

Стабильные изотопы $\left(\delta^{13} \mathrm{C}, \delta^{18} \mathrm{O}, \delta \mathrm{D}\right)$ активно используются при выявлении генезиса вод [Boral et al. 2019], их взаимодействии с окружением: грунтами [Santucci et al., 2019], породами [Cartwright et al. 2000; Aydin et al. 2020], атмосферой [Soulsby et al., 2015], загрязненности вод [Xia et al. 2020]. Отношения $\delta^{18} \mathrm{O}$ и $\delta \mathrm{D}$ используются для построения глобальной линии метеорных вод (Global Meteoric Water Line - GMWL) [Craig, 1961] и локальных линий метеорных вод (Local Meteoric Water Line - LMWL) [Aydin et al. 2020; Santucci et al., 2019; Xia et al. 2020].

В таблице 3 приведены данные по изотопным отношениям $\delta^{18} \mathrm{O}$ и $\delta \mathrm{D}$ рассолов, которые варьируют в широких пределах: от -133 до -17,5 \%о для $\delta \mathrm{D}$ и от $-17,0$ до -2,5 \%о для $\delta^{18} \mathrm{O}$. Изученная коллекция представлена рассолами трубки Удачная (средний и 
верхний кембрий) и рассолами нефтяных месторождений южных и западных районов Сибирской платформы (рифей, венд, венд-кембрий). Из рисунка рис. 9а видно, что для всех рассолов наблюдается отклонение значений их отношений $\delta^{18} \mathrm{O}$ и $\delta \mathrm{D}$ от GMWL и в зависимости от возраста отложений. Так, рассолы верхнекембрийского и рифейского комплексов располагаются ниже GMWL, а для среднекембрийских, венд-кембрийских и вендских характерно их отклонение в сторону обогащения легкими изотопами кислорода. Обеднение изотопного состава вод легким изотопом $\delta^{18} \mathrm{O}$ и положительный сдвиг относительно GMWL, происходит вследствие активного испарения вод [Chafouq et al. 2018, Newman et al., 2020]. Положительные сдвиги отношения $\delta^{18} \mathrm{O}$ объясняют взаимодействием вод с изотопно-тяжелыми кислородсодержащими породами и их изотопным обменом [Aydin et al. 2020]. Наибольшие положительные сдвиги наблюдаются для карбонатных высокотемпературных резервуаров [Truesdell et al., 1980]. Для эффективного протекания изотопного обмена требуются умеренно высокие температуры (50-200 드) и длительное время взаимодействия в системе вода-порода [Aydin et al. 2020]. Поэтому обогащение верхнекембрийских и рифейских рассолов тяжелым изотопом кислорода может быть объяснено более высокими температурами климата в заданные эпохи и соседством карбонатного материала, обогащенного изотопом ${ }^{18} \mathrm{O}$. Как известно [Томиленко и др., 2017; Горнова и др., 2007], гранатам и кальцитам трубки Удачной свойственны довольно «тяжелые» изотопные отношения $\delta^{18} \mathrm{O}$. Поэтому, гипотеза обогащения вод изотопом ${ }^{18} \mathrm{O}$ в результате изотопного обмена в системе «вода-порода» в течение длительного периода времени выглядит правдоподобной. Полученные значения $\delta^{18} \mathrm{O}$ рассолов верхнекембрийского и рифейского возрастов располагаются на линии Сl Са рассолов седиментационно-метаморфического генезиса, предложенной в работе [Алексеева, Алексеев., 2018] для рассолов кимберлитовых тел. Таким образом, эти рассолы, по-видимому, имеют седиментационно-метаморфический генезис. 
Для рассолов среднекембрийского, венд-кембрийского и вендского комплексов характерны отрицательные сдвиги $\delta^{18} \mathrm{O}$ относительно GMWL. Отношения $\delta \mathrm{D}$ варьирует от $-58,7$ до $-34,5 \%$, а $\delta^{18} \mathrm{O}$ от $-12,6$ до $-8,4$ \%. Большую часть значений $\delta^{18} \mathrm{O}$ и $\delta \mathrm{D}$ можно ограничить областью, обозначенной синим эллипсом. Обогащение вод легкими изотопами кислорода и смещение их изотопных отношений выше GMWL в литературе [Andreo et al. 2004], как правило, объясняют эффектами сезонности и связанными с ними изменениями температурного режима, влажности и процессами вторичного испарения. Отрицательное отклонение изотопных составов характеризует осадки холодного периода года. На рисунке 9 видна корреляция изотопных отношений $\delta^{18} \mathrm{O}$ (б) и $\delta \mathrm{D}$ (в) изученных рассолов от их общей минерализации. Установлено отклонение вод верхнекембрийского комплекса трубки Удачной в сторону малой минерализации, что связано с частичным их разбавлением метеорными водами. K аналогичным выводам приходят и авторы работ [Алексеева, Алексеев, 2018; Алексеев и др., 2007].

Анализ изотопных отношений $\delta^{13} \mathrm{C}$ растворенного неорганического углерода исследованных рассолов $\left(\delta^{13} \mathrm{C}_{\text {DIC }}\right)$ представляет особый интерес. Как известно [Das et. al, 2005; Mickler et al., 2019], при интерпретации данных, исследователи опираются на процессы взаимодействия вод с окружением [Zhang et al., 1995; Górka et al., 2011; Cotovicz et al., 2019]. В таблице 3 представлены данные по изотопным отношениям $\delta^{13} \mathrm{C}_{\mathrm{DIC}}$ рассолов, которые изменяются в интервале значений: от -31 до $+12,7$ \%о, что, указывает на широкий спектр соединений и процессов, участвующих в формировании гидрокарбонатиона рассолов. Учитывая седиментационно-метаморфический генезис рассолов, становится очевидным невозможность участия в формировании DIC обмена изотопами с атмосферой, вегетационного обмена, испарения и дегазации вод. В данном случае основным представляется изотопный обмен гидрокарбонат-иона с окружающими породами и жизнедеятельность микроорганизмов. 
Карбонатные породы в основном сформированы из морских систем, богатых тяжелыми изотопами углерода и имеющими значения отношений $\delta^{13} \mathrm{C}$ близкие к нулю [Keith et al., 1964; Hoefs, 2018]. Принимая во внимание значение коэффициента фракционирования между карбонатом и гидрокарбонат-ионом $\varepsilon_{\mathrm{c}-\mathrm{b}}=1,85$ при $20{ }^{\circ} \mathrm{C}$ [Emrich et al., 1970] можно оценить вероятное значение $\delta^{13} \mathrm{C}_{\mathrm{DIC}}$, получаемое при исключительном обмене карбонатная порода - гидрокарбонат-ион, равное при заданных условиях -1,85 \%. Разумеется, для точных определений следует учитывать зависимость величины $\varepsilon_{c-b}$ от температуры [Hoefs, 2018], но здесь ограничимся оценкой возможных значений величины $\delta^{13} \mathrm{C}_{\text {DIC }}$ в модельных условиях. Модельным значениям отвечает образец 216-230, отобранный из скважины трубки Удачная. В остальных случаях наблюдается отклонение от модельного случая (-1,85 \%о). Небольшие отрицательные экскурсы значений $\delta^{13} \mathrm{C}_{\mathrm{DIC}}$ могут быть объяснены участием древних растений с фотосинтезом типа Сз. Для резервуаров большинства изученных рассолов, по-видимому, характерно наличие биогенных процессов, смещающих изотопное отношение $\delta^{13} \mathrm{C}_{\text {DIC }}$ в положительную сторону в случае преобладания метаногенных процессов (образцы ДС-465, 172, 412, 578 и 586) и в сторону обогащения легкими изотопами при преобладании SMT-процессов (211200, 211-250, 504, 675, 727, 116-13 и 133-16). Особенно сильно эффект метаногенной бактериальной активности наблюдается для образца 5-465, где значения $\delta^{13} \mathrm{C}_{\text {DIc }}$ достигают аномальных $+12,7$ \%. Эффект SMT-активности в наибольшей степени проявляется в образцах рифейских отложений и, отдельно, в образце 504, где величина $\delta^{13} \mathrm{C}_{\mathrm{DI}}$ составляет $-31,0 \%$ \%

C увеличением возраста в целом наблюдается преобладание механизмов, приводящих к обогащению углекислоты вод легкими изотопами (см. табл. 3). Вероятно, этот тренд можно объяснить сменой типов бактериальных колоний по мере увеличения возраста рассолов. Логично, что для реализации механизмов SMT необходимо наличие метана в среде. Поэтому, можно выстроить гипотетическую цепь преобразования углерода 
рассолов изученных отложений: углеродсодержащие органические останки (DIC, обусловленный взаимодействием вода порода) $\rightarrow$ процесс метаногенеза (образование метана и обеднение DIC легкими изотопами) $\rightarrow$ процессы SMT (накопление изотопнолегкого DIC).

Большая часть представленных в работе рассолов была проанализирована на состав изотопных отношений ${ }^{87} \mathrm{Rb} /{ }^{86} \mathrm{Sr}$ и ${ }^{87} \mathrm{Sr} /{ }^{86} \mathrm{Sr}$ (см. табл. 3). На рисунке 10 представлена гистограмма распределения изотопных отношений ${ }^{87} \mathrm{Sr} /{ }^{86} \mathrm{Sr}$. Видно, что с увеличением возраста водоносных комплексов, растут и значения отношений ${ }^{87} \mathrm{Sr} /{ }^{86} \mathrm{Sr}$. Наименьшие величины (от 0,70813 до 0,70926) характерны для вод кембрийских и венд-кембрийских отложений, затем наблюдается постепенное возрастание ${ }^{87} \mathrm{Sr} /{ }^{86} \mathrm{Sr}$ отношения в рассолах вендских отложений (от 0,70955 до 0,71440) и, наконец, ярко-выраженные максимальные значения (0,71984-0,71985) для рифейских рассолов.

Как известно [Alexeev et al., 2019], значения отношений ${ }^{87} \mathrm{Sr} /{ }^{86} \mathrm{Sr}$ вод изменяются в соответствии с содержанием радиогенного стронция, являющегося продуктом радиоактивного распада ${ }^{87} \mathrm{Rb}$ из первичного источника - пород и вод палеоокеана. Исследователи чаще всего используют концепцию накопления тяжелого изотопа ${ }^{87} \mathrm{Sr}$ в замкнутых системах с течением времени (см. рис. 10б), исходя из которой, при прочих равных условиях, для более древних отложений должны наблюдаться большие значения отношений ${ }^{87} \mathrm{Sr} /{ }^{86} \mathrm{Sr}$. Для исследованных рассолов (рис. 10а) наблюдается закономерное возрастание содержания тяжелого изотопа стронция по мере перехода от более молодых отложений к более древним.

Отношения ${ }^{87} \mathrm{Sr} /{ }^{86} \mathrm{Sr}$ вод древних сингенетичных вод принято сравнивать со значениями отношений вод древнего океана соответствующего геологического периода. Водам океана, существовавшего в рифее и венде, соответствует интервал ${ }^{87} \mathrm{Sr} /{ }^{86} \mathrm{Sr}:$ от 0,7073 до 0,7086. Более позднему, кембрийскому океану, соответствуют воды с ${ }^{87} \mathrm{Sr} /{ }^{86} \mathrm{Sr}$ от 0,7081 до 0,7092. При этом последние практически совпадают со значениями 
современного океана [McArthur et al., 2012]. Очевидно, что исследованные рассолы кембрия $\left({ }^{87} \mathrm{Sr} /{ }^{86} \mathrm{Sr}=0,70813-0,70926\right)$ хорошо коррелируют с литературными данными. При этом четкой корреляции между ${ }^{87} \mathrm{Rb} /{ }^{86} \mathrm{Sr}$ и ${ }^{87} \mathrm{Sr} /{ }^{86} \mathrm{Sr}$ не выявлено. Это может указывать как на процессы смешения при инфильтрации более молодых вод, так и на эволюционные процессы в системе вода - горная порода. К аналогичным выводам пришли и авторы работы [Alexeev et al., 2019], наблюдавшие значения отношений ${ }^{87} \mathrm{Sr} /{ }^{86} \mathrm{Sr}$, существенно превышающие уровень современного океана, для рассолов венд-кембрийских отложений.

\section{Геохимия нефтепроявлений}

Проявления нефти, газа и природных битумов различного масштаба в кимберлитовых трубках Далдыно-Алакитского алмазоносного района встречаются повсеместно. Наиболее широко они распространены во вмещающих отложениях и непосредственно в рудных телах трубки Удачная. Характер нефтепроявлений во вмещающих породах и кимберлитах различен [Бодунов и др., 1986]. Отсутствует их четкая пространственная связь (см. рис. 3). Данные визуальной документации керна свидетельствуют о том, что нефтенасыщенность кимберлитов в целом в несколько раз меньше, чем вмещающих пород. По групповому составу и данным ИК- и УФспектроскопии проявления представлены нефтями, мальтами, и реже озокеритоподобными соединениями [Зуева и др., 1987]. Наиболее насыщены вмещающие породы северовосточного фланга кимберлитового тела. Здесь нефти и битумы фиксируется буквально от поверхности до глубины в 700 м, достигая наибольшей интенсивности в интервале 250500 м. Толщина (мощность) нефтенасыщенных прослоев достигает 10-15 м. На западном фланге кимберлитового поля наибольшая нефтенасыщенность вмещающих пород фиксируется на глубинах 650-900 м, насыщен также интервал 1180- 1475 м. Толщина обильно пропитанных нефтью частей разреза достигает 11 м. На южном фланге нафтидопроявления отмечаются с глубин 100-150 м и до забоя скважин (1500 м). Как правило, ниже глубины 700 м, количество и интенсивность нефтепроявлений 
последовательно снижается. Во вмещающих, главным образом карбонатных породах, интенсивные проявления приурочены к разновидностям с относительно высокими коллекторскими свойствами: к кавернозно-поровым доломитам и трещиноватым известнякам. В рудных телах битумы встречаются в ксенолитах осадочных пород, а также в зонах дробления кимберлитов и в контактах с вмещающими породами.

На масс-хроматограммах фракций насыщенных углеводородов (УВ) выделяются по крайней мере два индивидуальных типа нефтей и мальт (рис.11а,б). Третья разновидность представлена смешением первых двух в процессе разновременных этапов миграции (рис.11в), а четвертая - из зоны контакта, изменена при эксплозии кимберлитов (рис.11г).

Самым распространенным является первый «постэксплозивный» тип нафтидов, близкий по всем геохимическим параметрам к нефтям Непско-Ботуобинской антеклизы и, в частности, нефтям Мирнинского свода [Бодунов и др.,1986; Чалая и др., 2002]. Для этого типа характерно распределение нормальных алканов с максимумом на относительно низкомолекулярных УВ $\left(\mathrm{C}_{16}-\mathrm{C}_{18}\right)$ и присутствие «древних» биометок - 12 и 13 монометилалканов. Среди изопреноидов фитан, как правило, преобладает над пристаном. Среди стерановых биомаркеров в нефтях и мальтах трубки Удачная существенно преобладают этилхолестаны, и также, как и в ботуобинских нефтях, идентифицированы весьма редкие соединения - секостераны [Каширцев и др., 2019]. В ароматических фракциях типичными для докембрийских и нижнепалеозойских нефтей Сибирской платформы являются гомологические ряды алкилбензолов и метилалкилбензолов (рис. 12) с ярко выраженными максимумами на С 21 [Иванова, Каширцев, 2010]. Высоко конденсированные ароматические УВ не характерны для удачнинских нефтей, а среди бии трициклической ароматики выделяется 1,7,8-триметилфенантрен - биомаркер, характерный для органического вещества планктоно-водорослевого происхождения (рис. 13).

Нефти второго (доэксплозионного) типа приурочены лишь к удачнинской свите в 
интервале глубин 1130-1430 м (см. рис. 11б). Для них характерен высокомолекулярный максимум нормальных алканов на $\mathrm{C}_{26}-\mathrm{C}_{27}$ и отсутствие 12 и 13 монометилалканов. Эти нафтиды на контакте с кимберлитами существенно изменены: деасфальтизированы и отличаются необычно высокомолекулярными парафинами с максимумом распределения на $\mathrm{C}_{36}$ (см. рис. 11 г).

В свое время И.С. Гольдберг и К.К. Макаров [Гольдберг, Макаров, 1966], изучая взаимоотношения битумопроявлений с трапами Сибирской платформы, выделили два этапа миграции углеводородных флюидов: дотрапповый и посттрапповый. По всей видимости первый из них может совпадать с доэксплозионным, т.е. с допозднедевонскораннекаменоугольным (возраст трубки) этапом миграции, а постэксплозионный - с постпермским (юрским?) основным этапом формирования большинства нефте- и битумопроявлений на склонах Анабарской антеклизы и Оленекского поднятия [Сафронов и др., 2005].

\section{ЗАКЛЮЧЕНИЕ}

Резюмируя вышесказанное можно сделать следующие выводы. В пределах рудных тел и вмещающих пород распространены преимущественно кислые рассолы (средние величины $\mathrm{pH}=5,5)$ с величиной общей минерализации от 94,3 до 391,3 г/дм³ $\mathrm{Cl}$ Ca и $\mathrm{Cl}$ Ca-Na состава. C глубиной происходит рост общей минерализации и содержаний основных солеобразующих компонентов до горизонта -365 (абс. м), где она достигает 391 г/дм³ , ниже наблюдается инверсия гидрогеохимического поля и на горизонте -650 (абс. м) ее величина не превышает 253 г/дм³. В целом, подземные рассолы кимберлитовых трубок Далдыно-Алакитского алмазоносного района характеризуются средней степенью метаморфизации химического состава и несут геохимические черты проявления процессов криогенного метаморфизма, что требует дальнейших исследований. В изученных рассолах в наибольшей степени концентрируются $\mathrm{Br}, \mathrm{Sr}, \mathrm{B}, \mathrm{Li}, \mathrm{I}, \mathrm{Si}, \mathrm{Mn}$ и Se. 
Детальный анализ отношений стабильных изотопов $\delta^{18} \mathrm{O}$ и $\delta \mathrm{D}$ вод и растворенного в них неорганического углерода $\delta^{13} \mathrm{C}$ показал, что изученные рассолы следует относить к седиментационно-метаморфическим. Для верхнекембрийских рассолов, вероятно, имело место частичное разбавление метеорными водами. Анализ значений $\delta^{13} \mathrm{C}_{\mathrm{DIC}}$ указывает на явное присутствие биогенного механизма генерации изотопного состава растворенной углекислоты. Обогащение гидрокарбонат-иона легкими и тяжелыми изотопами углерода определяется соотношением метаногенных и SMT-процессов в закрытых системах. Изотопные отношения ${ }^{87} \mathrm{Rb} /{ }^{86} \mathrm{Sr}$ и ${ }^{87} \mathrm{Sr} /{ }^{86} \mathrm{Sr}$ показали родство кембрийских рассолов изотопному составу древнего океана кембрийского времени.

На масс-хроматограммах фракций насыщенных углеводородов (УВ) выделяются по крайней мере два индивидуальных типа нефтей и мальт. Третья разновидность представлена смешением первых двух в процессе разновременных этапов миграции, а четвертая - из зоны контакта, изменена при эксплозии кимберлитов. Самым распространенным является первый «постэксплозивный» тип нафтидов, близкий по всем геохимическим параметрам к нефтям Непско-Ботуобинской антеклизы и, в частности, нефтям Мирнинского свода. Нефти второго (доэксплозионного) типа приурочены лишь к удачнинской свите в интервале глубин 1130-1430 м.

Исследования проводились при финансовой поддержке проекта ФНИ № 0331-20190025 и РФФИ в рамках научного проекта № 18-05-70074 «Ресурсы Арктики».

\section{ЛИТЕРАТУРА}

Александров И.Н., Шубин Г.В., Кирюшин Д.И., Заровняев Б.Н. Мониторинг теплового режима массива уступов карьера «Удачный» // Горн. информ. аналит. бюл. 2003, № 7, с. 1113.

Алексеев С.В. Криогидрогеологические системы Якутской алмазоносной провинции. Новосибирск: Гео, 2009, 319 с. 
Алексеев С.В., Алексеева Л.П., Борисов В.Н., Шоуакар-Сташ О., Фрейп Ш., Шабо Ф., Кононов А.М. Изотопный состав (H, O, $\mathrm{Cl}, \mathrm{Sr})$ подземных рассолов Сибирской платформы // Геология и геофизика. 2007, т. 48. № 3, с. 291-304.

Алексеев С.В., Алексеева Л.П., Гладков А.С., Трифонов Н.С., Серебряков Е.В., Павлов С.С., Ильин А.В. Рассолы глубоких горизонтов кимберлитовой трубки Удачная // Геодинамика и тектонофизика. 2018, т. 9, № 4, с. 1235-1253.

Алексеева Л.П., Алексеев С.В. Геохимия подземных льдов, соленых вод и рассолов криоартезианских бассейнов северо-востока Сибирской платформы // Геология и геофизика. 2018, т. 59. № 2, с. 183-197.

Алексеева Л.П., Алексеев С.В. Геохимия подземных льдов, соленых вод и рассолов Западной Якутии / Л.П. Алексеева, С.В. Алексеев; Рос. акад. наук, Сиб. отд-ние, Институт земной коры. Новосибирск: Академическое изд-во «Гео», 2019, 214 с.

Атрощенко Ф.Г. Оценка гидрогеологических условий подземной разработки месторождения трубки «Удачная» // Геоэкология. Инженерная геология. Гидрогеология. Геокриология. 2012, № 5, с. 414-421.

Балобаев В.Т., Девяткин В.Н. Мерзлотно-геотермические условия Западной Якутии // Теплофизические исследования криолитозоны Сибири. Новосибирск: Наука, 1983, с. 2234.

Бодунов Е.И., Белецкий В.Л., Фрадкин Г.С., Зуева И.Н. Геология, гидрогеология и геохимия нефти и газа южного склона Анабарской антеклизы. Якутск: ЯФ СО АН СССР, 1986, 176 c.

Гольдберг И.С., Макаров К.К. Основные этапы и стадии миграции нефти в Тунгусской синеклизе и Анабарской антеклизе (Сибирская платформа) // Геология и геофизика. 1966, № 3, с. 3-19. 
Горнова М.А., Полозов А.Г., Игнатьев А.В., Веливецкая Т.А. Перидотиты кимберлитовой трубки Удачная: «немантийные» изотопные отношения кислорода в гранатах // ДАН. 2007, т. 415, № 1, с. 91-95.

Григорьев Н. А. Распределение химических элементов в верхней части континентальной коры // Уральский геологический журнал. 2010, № 3 (75), с.85-90.

Дроздов А.В. Подземное захоронение дренажных рассолов в многолетнемерзлые породы (на примере Удачнинского ГОКа в Западной Якутии) // Геоэкология. 2005, № 3, с. 234-243.

Дроздов А.В., Егоров К.Н., Готовцев С.П., Климовский И.В. Особенности гидрогеологического строения и гидрохимической зональности кимберлитовой трубки «Удачная» // Комплексные мерзлотно-гидрогеологические исследования. Якутск, ИМЗ СО AH CCCP, 1989, с. 145-155.

Дроздов А.В., Мельников А.И. Прогноз нефтегазоопасных зон на руднике «Удачный» (Якутия) с использованием геосистемного подхода // Известия Сибирского отделения Секции наук о Земле РАЕН. 2015, № 4 (53), с. 37-49.

Зорькин Л.М. Геохимия газов пластовых вод нефтегазоносных бассейнов. М.: Недра, 1973, 224 c.

Зуева И.Н., Уткина Н.А., Бодунов Е.И. Химическая структура нафтидов ДалдыноАлакитского района (по данным ИК- и УФ-спектроскопии) // Геология и геохимия нефтеносных и угленосных районов Якутии. Якутск: ЯФ СО АН СССР, 1987, с. 99-110.

Иванов А.И., Вартанян С.С., Черных А.И., Волчков А.Г., Голубев Ю.К., Звездов В.С., Кузнецов В.В., Васюков В.Е., Голубев С.Ю., Конкин В.Д., Котельников Е.Е., Мансуров Р.Х., Прусакова Н.А., Столяренко В.В., Арсентьева И.В., Серавина Т.В., Корчагина Д.А., Барышев А.Н., Донец А.И., Ручкин Г.В., Чекваидзе В.Б. Состояние и перспективы развития минерально-сырьевой базы алмазов, золота, меди, свинца, цинка Российской Федерации (по результатам работ ФГУП ЦНИГРИ за 2012-2015 гг.) // Отечественная геология. 2016, № 5, с. 1-52. 
Иванова И.К., Каширцев В.А. Особенности распределения моноалкилбензолов состава С12Н18 - C27Н48 в венд-кембрийских нефтях Сибирской платформы // Геология и геофизика. 2010, т. 51, № 11, с. 1539- 1544.

Каширцев В.А., Парфенова Т.М., Моисеев С.А., Черных А.В., Новиков Д.А., Бурштейн Л.М., Долженко К.В., Рогов В.И., Мельник Д.С., Зуева И.Н., Чалая О.Н. Прямые признаки нефтегазоносности и нефтематеринские отложения Суханского осадочного бассейна Сибирской платформы // Геология и геофизика. 2019, т. 60, № 10, с. 1472-1487.

Климовский И.В., Готовцев С.П. Криолитозона Якутской алмазоносной провинции. Новосибирск: Наука, 1994, 167 с.

Лазебник А.П. Отчет о результатах комплексной гидрогеологической и инженерногеологической съемки Далдыно-Алакитского района масштаба 1:200 000 листов Q-49-XVI, XVII, XXII за 1985-88 гг. Якутск, 1988, 504 с.

Легостаева Я.Б., Попов В.Ф., Аммосова М.К., Ксенофонтова М.И. Гидрогеологические условия и геоэкологическая ситуация на территории подземных техногенных хранилищ при утилизации дренажных рассолов Удачнинского горно-обогатительного комбината // Отечественная геология. 2018, № 3, с. 93-102.

Новиков Д.А., Ильин А.В., Черных А.В., Дульцев Ф.Ф. Микроэлементный состав рассолов кимберлитовой трубки «Удачная» (Сибирская платформа) // Труды Ферсмановской научной сессии ГИ КНЦ РАН. 2020, № 17, с. 411-415.

Павлов В.А. Отчёт о результатах работ по комплексной гидрогеологической и инженерногеологической съёмке масштаба 1: 50000 в Далдыно-Алакитском районе в пределах листов Q-49-57-ВГ, Q-49-67-ВГ, Q-49-68-АБВ, Q-49-69-A, Q-49-79-АБ, Q-49-80-А за 197983 гг. Якутск, 1983, 765 с. 
Сафронов А.Ф., Зинчук Н.Н., Каширцев В.А., Конторович А.Э., Бондарев Э.А., Зуева

И.Н., Чалая О.Н. Нафтидопроявления в кимберлитовых трубках и вмещающих породах Якутской алмазоносной провинции // Геология и геофизика. 2005, т. 46, № 2, с. 151-159.

Томиленко А.А., Дублянский Ю.В., Кузьмин Д.В., Соболев Н.В. Изотопный состав углерода и кислорода магматических кальцитов из кимберлитов трубки Удачнаявосточная, Якутия // ДАН. 2017, т. 475, № 3, с. 316-319.

Устинова 3.Г. К гидрохимии кимберлитовых трубок Якутии // Вопросы геохимии подземных вод. М.: Недра, 1964, с. 237-252.

Чалая О.Н., Зуева И.Н., Каширцев В.А., Трущелева Г.С., Лифшиц С.Х., Карелина O.С. Состав и свойства нефтей Иреляхского месторождения //Физико-технические проблемы добычи, транспорта и переработки нефти и газа в северных регионах, Якутск. ЯФ Изд-ва СО РАН, 2002, с. 202-207.

Шварцев С.Л. Химический состав и изотопы стронция рассолов Тунгусского бассейна в связи с проблемой их формирования // Геология и геофизика. 2000, № 11, с. 1170-1184.

Alexeev S., Alexeeva L., Shouakar-Stash O. Strontium isotopic ratio in brines from the northeast of the Angara-Lenskiy artesian basin // E3S Web of Conferences. 2019, v. 98, № 12001.

Andreo B., Linan C., Carrasco F., Jimenez de Cisneros C., Caballero F., Mudry J. Influence of rainfall quantity on the isotopic composition (18O and $2 \mathrm{H})$ of water in mountainous areas. Application for groundwater research in the Yunquera-Nieves karst aquifers (S Spain) // Applied Geochemistry. 2004, v. 19, pp. 561-574.

Aydin H., Karakuş H., Mutlu H. Hydrogeochemistry of geothermal waters in eastern Turkey: Geochemical and isotopic constraints on water-rock interaction // Journal of Volcanology and Geothermal Research. 2020, v. 390, № 106708.

Banner J.L. Radiogenic isotopes: systematics and applications to earth surface processes and chemical stratigraphy / Earth-Sci. Rev. 2004, v.65, issue 3-4, pp. 141-194. 
Boral S., Sen I.S., Ghosal D., Peucker-Ehrenbrink B., Hemingway J.D. Stable water isotope modeling reveals spatio-temporal variability of glacier meltwater contributions to Ganges River headwaters // Journal of Hydrology. 2019, v. 577, № 123983.

Cartwright I., Weaver T., Tweed S., Ahearne D., Cooper M., Czapnik C., Tranter J. O, H, C isotope geochemistry of carbonated mineral springs in central Victoria, Australia: sources of gas and water-rock interaction during dying basaltic volcanism // Journal of Geochemical Exploration, 2000, v. 69-70, pp. 226-257.

Chafouq D., Mandour A.El, Elgettafi M., Himi M., Chouikri I., Casas A. Hydrochemical and isotopic characterization of groundwater in the Ghis-Nekor plain (northern Morocco) // Journal of African Earth Sciences. 2018, v. 139, pp. 1-13.

Cotovicz Jr. L.C., Knoppers B.A., Deirmendjian L., Abril G. Sources and sinks of dissolved inorganic carbon in an urban tropical coastalbay revealed by $\delta 13 \mathrm{C}-\mathrm{DIC}$ signals // Estuarine, Coastal and Shelf Science. 2019, v. 220, pp. 185-195.

Craig H. Isotopic variations in meteoric waters // Science. 1961, v. 133, pp. 1702-1703.

Das A., Krishnaswami S., Bhattacharya S.K. Carbon isotope ratio of dissolved inorganic carbon (DIC) in rivers draining the Deccan Traps, India: Sources of DIC and their magnitudes // Earth and Planetary Science Letters. 2005, v. 236, issues 1-2, pp. 419-429.

Emrich K., Ehhalt D.H., Vogel J.C. Carbon isotope fractionation during the precipitation of calcium carbonate // Earth and Planetary Science Letters. 1970, v. 8, issue 5, pp. 363-371.

Górka M., Sauer P.E., Lewicka-Szczebak D., Jędrysek M.-O. Carbon isotope signature of dissolved inorganic carbon (DIC) in precipitation and atmospheric CO2 // Environmental PollutionVolume. 2011, v. 159, issue 1. pp. 294-301.

Hoefs J. Stable isotope geochemistry 8th edition: Springer International Publishing AG, part of Springer Nature 2018, 460 p.

Keith M.L., Weber J.N. Isotopic composition and environmental classification of selected limestone and fossils // Geochim. Cosmochim. Acta. 1964, v. 28, pp. 1787- 1816. 
McArthur J.M., Howarth R.J., Shields G.A. The Geologic Time Scale. Chapter 7. 2012, pp. 127-144.

Mickler P.J., Carlson P., Banner J.L., Breecker D.O., Stern L., Guilfoyle A. Quantifying carbon isotope disequilibrium during in-cave evolution of drip water along discreet flow paths // Geochimica et Cosmochimica Acta. 2019, v. 244, pp. 182-196.

Newman C.P. Poulson S.R., Hanna B. Regional isotopic investigation of evaporation and water-rock interaction in mine pit lakes in Nevada, USA // Journal of Geochemical Exploration. 2020, v. 210, № 106445.

Novikov D.A. Hydrogeochemistry of the Arctic areas of Siberian petroleum basins // Petroleum Exploration and Development. 2017, v. 44, issue 5, pp. 780-788.

Santucci L., Sanci R., Carol E., Villalba E., Panarello H. Using H, O, Rn isotopes and hydrometric parameters to assess the surface water-groundwater interaction in coastal wetlands associated to the marginal forest of the Río de la Plata // Continental Shelf Research. 2019, v. 186, pp. 104-110.

Soulsby C., Birkel C., Geris J., Dick J., Tunaley C., Tetzlaff D. Stream water age distributions controlled by storage dynamics and nonlinear hydrologic connectivity: modeling with highresolution isotope data // Water Resour. Res. 2015, v. 51, pp. 7759-7776.

Truesdell A.H., Hulston J.R. Isotopic evidence on environments of geothermal systems. In: Handbook of Environmental Isotope Chemistry, the Terrestrial Environment. Elsevier. 1980, pp. $179-226$.

Xia Z., Zheng Y., Stelling J.M., Loisel J., Huang Y., Yu Z. Environmental controls on the carbon and water ( $\mathrm{H}$ and $\mathrm{O}$ ) isotopes in peatland Sphagnum mosses // Geochimica et Cosmochimica Acta. 2020, v. 277, pp. 265-284.

Zhang J., Quay P.D., Wilbur D.O. Carbon isotope fractionation during gas-water exchange and dissolution of CO2 // Geochimica et Cosmochimica Acta. 1995, v. 59, issue 1, pp. 107-114. 
Рис. 1. Местоположение кимберлитовой трубки Удачкая (составили Салихов Р.Ф., Охлопков В.И. по материалам Амакинской ГРЭ)

1 - техногенные грунты; 2 - аллювиальные суглинки, супеси, галечники (I терраса); 3 аллювиальные суглинки, пески, галечники (II терраса); 4 - поздняя девонская-ранняя каменноугольная эпохи. Далдыно-Алакитский кимберлитовый комплекс; 5-12 - верхний кембрий. (5-7) Мархинская свита. Вторая-четвертая пачки. (8, 11) Моркокинская свита. Верхняя и нижняя подсвиты. (9-10) Онхойюряхская свита. Верхняя и нижняя пачки. 13 нижний ордовик. Олдондинская свита. Первая пачка. 14 - триас. Оленёк-велингнинский комплекс габбро-долеритов и такситовых долеритов. 15 - граница между разновозрастными образованиями; 16 - горизонтали рельефа; 17 - предполагаемые линии тектонических нарушений; 18 - кузьмовский феррогаббровый долеритовый комплекс; 19 абсолютная отметка, м.

Рис. 2. Фото - общий вид карьера кимберлитовой трубки Удачная с высоты птичьего полета (по материалам Удачнинского ГОКа)

Рис. 3. Модель рудных тел кимберлитовой трубки Удачная (по данным института «Якутнипроалмаз»)

1 - балансовые запасы, 2 - забалансовые запасы, 3 - отработанное пространство, 4 границы отработанных рудных тел, 5 - водоносные комплексы, 6 - горные выработки; состав пород: 7 - доломиты, 8 - известняки, 9 - рифовые эпифитоновые известняки, 10 глинистые известняки; 11 - сплошь пропитанные нефтью участки пород, 12 газопроявления.

\section{Рис. 4. Диаграмма Пайпера состава рассолов кимберлитовой трубки Удачная}

а) рудные тела: 1 - тр. Удачная (2019 г); Западное рудное тело: 2 - гор. -320м; 3 - гор. -365м; Восточное рудное тело: 4 - гор. -320м; 5 - гор. -365м;

б) водосборники: 1 - гор. -365м; 2- гор. -380м; 3 - гор. -480м; 4 - гор. -580м; 5 - гор. $-650 \mathrm{M}$.

Рис. 5. Спектр распределения элементов в рассолах кимберлитовой трубок Удачная и Нюрбинская

Трубка Удачная: 1 - верхнекембрийский водоносный комплекс, 2 - среднекембрийский водоносный комплекс трубки; 3 - ордовикский водоносный комплекс трубки Нюрбинская. 
Рис. 6. Коэффициенты концентрации элементов в рассолах кимберлитовой трубки Удачная относительно содержаний элементов в осадочном слое (а), карбонатах (б) и эвапоритах (в) (по [Григорьев, 2010]).

Условные обозначения см. на рис. 5.

Рис. 7. Изменение общей газонасыщенности рассолов с глубиной (по [Дроздов, Мельников, 2015]) (а), диаграммы общего состава газов (б) и состава тяжелой углеводородной фракции (в) водорастворенных газов среднекембрийского водоносного комплекса кимберлитовой трубки Удачная

Рис. 8. Средний состав ВРГ среднекембрийского водоносного комплекса кимберлитовой трубки Удачная

Рис. 9. Изотопные отношения $\delta D-\delta^{18} O$ (а) в рассолах, зависимость $\delta^{18} O$ (б) и $\delta D$ (в) от общей минерализации рассолов

Рис. 10. Отношение ${ }^{87} \mathrm{Sr} /{ }^{86} \mathrm{Sr}$ в исследованных рассолах (а), концепция накопления ${ }^{87} \mathrm{Sr}$ в замкнутом резервуаре (б) [Banner J.L., 2004].

Рассолы водоносных комплексов: 1-4 - верхнекембрийского; 5-7 - среднекембрийского; 8 - венд-кембрийского; 9-12 - вендского; 13-14 - рифейского;

Рис. 11. Масс-хроматограммы насыщенных углеводородов основных типов нафтидов района трубки Удачная

a - «ботуобинский» постэксплозионный тип; б - доэксплозионный (парафиновый) тип; в смешанный; г - измененный в зоне контакта.

Рис. 12. Масс-хроматограммы ароматических углеводородов «легкой» фракции

Рис. 13. Масс-хроматограммы ароматических углеводородов «средней» фракции 
Таблица 1.

\begin{tabular}{|c|c|c|c|c|c|c|c|c|c|c|c|c|c|c|c|c|}
\hline $\begin{array}{l}\text { № скв., } \\
\text { объект }\end{array}$ & $\mathrm{pH}$ & $\mathrm{HCO}_{3}^{-}$ & $\mathrm{SO}_{4}{ }^{2-}$ & $\mathrm{Cl}^{-}$ & $\mathrm{Ca}^{2+}$ & $\mathrm{Mg}^{2+}$ & $\mathrm{Na}^{+}$ & $\mathrm{K}^{+}$ & $\mathrm{M}$ & $\mathrm{Br}$ & $\mathrm{Li}$ & $\mathrm{Rb}$ & $\mathrm{Sr}$ & $\mathrm{rNa} / \mathrm{rCl}$ & $\mathrm{rCa} / \mathrm{rMg}$ & $\mathrm{Ca} / \mathrm{Cl}$ \\
\hline \multicolumn{17}{|c|}{ Верхнекембрийский водоносный комплекс } \\
\hline 33 & 6,85 & 80 & 1030 & 30560 & 7400 & 4130 & 4150 & 820 & 48600 & 570 & - & - & 130 & 0,21 & 1,09 & 0,24 \\
\hline 314 & 6,35 & 40 & 460 & 124900 & 24960 & 21020 & 11470 & 3340 & 188800 & 2570 & - & - & 515 & 0,14 & 0,72 & 0,20 \\
\hline $211 л$ & 6,16 & 46 & 434 & 64433 & 20100 & 3498 & 11820 & 2180 & 102914 & 1297 & 38 & 1,4 & 315 & 0,28 & 3,48 & 0,31 \\
\hline 216л & 5,13 & 19 & 644 & 104725 & 25590 & 13150 & 10700 & 3018 & 158403 & 2078 & 46 & 1,7 & 436 & 0,16 & 1,18 & 0,24 \\
\hline $211 л$ & 6,22 & 103 & 381 & 125500 & 40120 & 6750 & 13900 & 5401 & 192863 & 2927 & 79 & 4,0 & 546 & 0,17 & 3,60 & 0,32 \\
\hline 216л & 4,96 & 10 & 460 & 121100 & 25000 & 14600 & 20000 & 3420 & 185343 & 2010 & 50 & 2,1 & 518 & 0,25 & 1,04 & 0,21 \\
\hline 1Д & 4,45 & 200 & 100 & 234900 & 77100 & 14400 & 28400 & 15200 & 374280 & 4100 & 292 & 24,5 & 1707 & 0,19 & 3,25 & 0,33 \\
\hline 2Д & 4,65 & 300 & 100 & 237500 & 78700 & 15200 & 26400 & 15400 & 377710 & 4200 & 297 & 25,1 & 1672 & 0,17 & 3,14 & 0,33 \\
\hline ЗД & 4,35 & 200 & 100 & 231700 & 77100 & 14800 & 27000 & 15300 & 370300 & 4200 & 297 & 24,8 & 1351 & 0,18 & 3,16 & 0,33 \\
\hline 101 & 6,85 & 70 & 760 & 77660 & 24100 & 3830 & 13830 & 3790 & 125530 & 1490 & - & - & - & 0,27 & 3,82 & 0,31 \\
\hline \multicolumn{17}{|c|}{ Среднекембрийский водоносный комплекс } \\
\hline $\begin{array}{l}\text { камера } \\
\text { УПП-7 }\end{array}$ & 6,18 & 100 & 425 & 124189 & 40000 & 5500 & 21400 & 5055 & 196674 & - & 77 & 5,5 & 471 & 0,27 & 4,41 & 0,32 \\
\hline СКв. 5 & 4,64 & 61 & 247 & 247800 & 87240 & 13647 & 22975 & 17147 & 391280 & 5817 & 205 & 16,9 & 1545 & 0,14 & 3,88 & 0,35 \\
\hline $\begin{array}{l}\text { ДС- } \\
4.2 \mathrm{~B} \\
\end{array}$ & 4,9 & 96 & 211 & 239625 & 84100 & 12900 & 22500 & 12670 & 372634 & 5572 & 159 & 11,8 & 1059 & 0,14 & 3,95 & 0,35 \\
\hline 329 & 5,35 & 110 & 230 & 200600 & 68540 & 11470 & 25910 & 11770 & 323600 & 4230 & - & - & 1086 & 0,20 & 3,63 & 0,34 \\
\hline 314 & 4,65 & 20 & 30 & 202700 & 67380 & 9650 & 26670 & 10000 & 320700 & 4160 & - & - & 1253 & 0,20 & 4,24 & 0,33 \\
\hline 308 & 4,3 & 20 & 100 & 236300 & 87720 & 13680 & 23300 & 15180 & 382880 & 4930 & - & - & 1315 & 0,15 & 3,89 & 0,37 \\
\hline 312 & 4,05 & 20 & 100 & 219900 & 78050 & 16320 & 13370 & 11750 & 343600 & 5080 & - & - & 1283 & 0,09 & 2,90 & 0,35 \\
\hline 306 & 4,25 & 110 & 70 & 253700 & 91880 & 16430 & 18050 & 18050 & 404300 & 5890 & - & - & 1581 & 0,12 & 3,39 & 0,36 \\
\hline 308 & 4,50 & 100 & 110 & 238100 & 81580 & 15840 & 16340 & 18360 & 376100 & 5660 & - & - & 1304 & 0,11 & 3,12 & 0,34 \\
\hline 30 & 4,95 & 120 & 150 & 218210 & 69400 & 17640 & 24960 & 12450 & 347800 & 4820 & - & - & 1083 & 0,18 & 2,39 & 0,32 \\
\hline
\end{tabular}

Примечание: «-» - нет данных.

Типовые пробы рассолов кимберлитовой трубки Удачная, мг/дм ${ }^{3}$ 
Таблица 2.

Состав водорастворенных газов среднекембрийского водоносного комплекса кимберлитовой трубки Удачная

\begin{tabular}{|c|c|c|c|c|c|c|c|c|c|c|c|c|c|c|c|c|}
\hline \multirow{2}{*}{ № СКв. } & \multicolumn{14}{|c|}{ Элементный состав, об. \% } & \multirow{2}{*}{$\frac{\mathrm{yB}}{\mathrm{N}_{2}}$} & \multirow{2}{*}{$\frac{\mathrm{CH}_{4}}{\Sigma \mathrm{TY}}$} \\
\hline & $\mathrm{CO}_{2}$ & $\mathrm{~N}_{2}$ & $\mathrm{He}$ & $\mathrm{H}_{2}$ & $\mathrm{CH}_{4}$ & $\mathrm{C}_{2} \mathrm{H}_{6}$ & $\mathrm{C}_{3} \mathrm{H}_{8}$ & $\mathrm{i}-\mathrm{C}_{4} \mathrm{H}_{10}$ & $\mathrm{n}-\mathrm{C}_{4} \mathrm{H}_{10}$ & $\mathrm{i}-\mathrm{C}_{5} \mathrm{H}_{12}$ & $\mathrm{n}-\mathrm{C}_{5} \mathrm{H}_{12}$ & $\mathrm{C}_{5} \mathrm{H}_{12}{ }^{*}$ & $\Sigma \mathrm{TУ}$ & УВ & & \\
\hline \multicolumn{17}{|c|}{ Горизонт - 320 м } \\
\hline KC-28 & 1,03 & 2,98 & 0,01 & 0,01 & 78,78 & 11,99 & 3,83 & 0,41 & 0,72 & 0,11 & 0,14 & 0,00 & 17,18 & 95,96 & 32 & 4,58 \\
\hline KC-39 & 0,96 & 2,38 & 0,00 & 0,02 & 66,61 & 18,56 & 7,90 & 1,03 & 1,78 & 0,30 & 0,46 & 0,00 & 30,04 & 96,65 & 41 & 2,22 \\
\hline KC-40 & 1,22 & 4,08 & 0,00 & 0,02 & 62,23 & 19,81 & 8,78 & 1,13 & 1,93 & 0,32 & 0,51 & 0,00 & 32,46 & 94,69 & 23 & 1,92 \\
\hline \multicolumn{17}{|c|}{ Горизонт - 365 м } \\
\hline KC-10 & 0,19 & 8,53 & 0,00 & 0,01 & 66,20 & 14,43 & 7,80 & 0,91 & 1,35 & 0,26 & 0,32 & 0,01 & 25,07 & 91,28 & 11 & 2,64 \\
\hline KC-13 & 0,19 & 5,38 & 0,01 & 0,01 & 67,53 & 14,33 & 8,25 & 1,19 & 2,02 & 0,43 & 0,64 & 0,01 & 26,88 & 94,41 & 17 & 2,51 \\
\hline KC-14 & 0,22 & 5,24 & 0,01 & 0,01 & 67,55 & 14,38 & 8,29 & 1,20 & 2,03 & 0,43 & 0,64 & 0,01 & 26,97 & 94,52 & 18 & 2,50 \\
\hline KC-15 & 1,22 & 6,70 & 0,01 & 0,01 & 68,15 & 13,54 & 6,98 & 1,02 & 1,60 & 0,34 & 0,42 & 0,01 & 23,92 & 92,06 & 14 & 2,85 \\
\hline KC-16 & 0,04 & 3,12 & 0,00 & 0,01 & 65,39 & 17,91 & 9,58 & 1,29 & 1,92 & 0,32 & 0,40 & 0,01 & 31,43 & 96,82 & 31 & 2,08 \\
\hline KC-67 & 0,00 & 4,53 & 0,01 & 0,02 & 66,81 & 14,71 & 7,47 & 1,54 & 2,96 & 0,85 & 1,08 & 0,02 & 28,62 & 95,44 & 21 & 2,33 \\
\hline KC-69 & 1,20 & 7,00 & 0,02 & 0,02 & 73,04 & 11,75 & 4,41 & 0,61 & 1,24 & 0,30 & 0,39 & 0,01 & 18,71 & 91,75 & 13 & 3,90 \\
\hline ЭС-15 & 1,44 & $\begin{array}{c}11,1 \\
7\end{array}$ & 0,04 & 0,01 & 73,67 & 8,62 & 3,34 & 0,44 & 0,86 & 0,19 & 0,22 & 0,00 & 13,68 & 87,35 & 8 & 5,39 \\
\hline ЭС-16 & 0,13 & 7,88 & 0,02 & 0,01 & 71,72 & 10,40 & 5,44 & 0,99 & 1,97 & 0,61 & 0,83 & 0,01 & 20,24 & 91,96 & 12 & 3,54 \\
\hline ЭС-23 & 1,23 & 7,49 & 0,02 & 0,01 & 72,55 & 11,05 & 5,05 & 0,68 & 1,26 & 0,31 & 0,35 & 0,00 & 18,71 & 91,25 & 12 & 3,88 \\
\hline ЭС-24 & 0,04 & $\begin{array}{c}10,4 \\
6 \\
\end{array}$ & 0,04 & 0,01 & 73,11 & 9,78 & 4,23 & 0,57 & 1,17 & 0,26 & 0,33 & 0,00 & 16,34 & 89,45 & 8 & 4,48 \\
\hline ЭС-25 & 1,23 & 6,82 & 0,02 & 0,01 & 71,81 & 11,71 & 5,49 & 0,73 & 1,40 & 0,35 & 0,41 & 0,00 & 20,10 & 91,91 & 13 & 3,57 \\
\hline ЭС-26 & 0,03 & $\begin{array}{c}10,5 \\
2\end{array}$ & 0,04 & 0,01 & 73,77 & 8,95 & 4,11 & 0,60 & 1,26 & 0,31 & 0,39 & 0,01 & 15,63 & 89,40 & 8 & 4,72 \\
\hline ЭС-28 & 2,48 & 9,16 & 0,03 & 0,02 & 70,14 & 10,04 & 4,96 & 0,74 & 1,54 & 0,38 & 0,49 & 0,01 & 18,17 & 88,31 & 10 & 3,86 \\
\hline ЭС-29 & 0,02 & 6,98 & 0,03 & 0,01 & 74,20 & 9,33 & 5,24 & 0,85 & 1,84 & 0,68 & 0,82 & 0,01 & 18,77 & 92,97 & 13 & 3,95 \\
\hline ЭС-30 & 0,01 & $\begin{array}{c}10,0 \\
3\end{array}$ & 0,02 & 0,00 & 68,25 & 10,65 & 6,34 & 0,95 & 2,06 & 0,78 & 0,89 & 0,02 & 21,70 & 89,95 & 9 & 3,15 \\
\hline ЭС-42 & 0,02 & 5,95 & 0,02 & 0,02 & 71,70 & 10,80 & 6,73 & 1,08 & 2,29 & 0,67 & 0,77 & 0,01 & 22,35 & 94,05 & 16 & 3,21 \\
\hline ЭС-64 & 0,14 & 15,2 & 0,02 & 0,00 & 71,10 & 7,58 & 4,04 & 0,55 & 0,93 & 0,21 & 0,19 & 0,00 & 13,51 & 84,61 & 5 & 5,26 \\
\hline
\end{tabular}




\begin{tabular}{|c|c|c|c|c|c|c|c|c|c|c|c|c|c|c|c|c|}
\hline & & 0 & & & & & & & & & & & & & & \\
\hline ЭС-90 & 0,66 & 7,73 & 0,01 & 0,03 & 67,56 & 13,08 & 6,18 & 1,01 & 2,18 & 0,58 & 0,94 & 0,01 & 23,98 & 91,54 & 12 & 2,82 \\
\hline ЭС-91 & 0,16 & 5,77 & 0,01 & 0,06 & 69,38 & 13,44 & 6,43 & 1,02 & 2,24 & 0,56 & 0,91 & 0,01 & 24,62 & 94,00 & 16 & 2,82 \\
\hline \multicolumn{17}{|c|}{ Горизонт - 380 м } \\
\hline скв 4Д & 0,82 & 2,21 & 0,00 & 0,01 & 78,00 & 11,38 & 4,85 & 0,69 & 1,37 & 0,28 & 0,39 & 0,01 & 18,97 & 96,97 & 44 & 4,11 \\
\hline $\begin{array}{c}\text { Среднее } \\
\text { : }\end{array}$ & 0,61 & 6,97 & 0,02 & 0,01 & 70,39 & 12,43 & 6,07 & 0,88 & 1,66 & 0,41 & 0,54 & 0,01 & 22,00 & 92,39 & 17 & 3,43 \\
\hline
\end{tabular}

Примечание: * - неопентан (диметилпропан). 
Таблица 3.

Изотопный состав рассолов кимберлитовой трубки Удачная и ряда гидрогеохимических эталонов Сибирской платформы 


\begin{tabular}{|c|c|c|c|c|c|c|c|c|c|c|c|}
\hline № пробы & Комплекс & $\mathbf{M}$ & $\delta^{13} C_{\text {VPDB }}, \%$ & $\delta^{13} \mathrm{C}, \%$ & $\begin{array}{c}\delta D_{\text {vsmow }} \\
\% \text { oo }\end{array}$ & $\delta D, \%$ & $\begin{array}{c}\delta^{18} \mathbf{O}_{\text {vsmow }} \\
\% \text {, }\end{array}$ & $\begin{array}{c}\delta^{18} \mathrm{O} \\
\%\end{array}$ & ${ }^{87} \mathbf{R b} /{ }^{86} \mathrm{Sr}$ & ${ }^{87} \mathrm{Sr} /{ }^{86} \mathrm{Sr}$ & $\pm 2 S D$ \\
\hline \multicolumn{12}{|c|}{ Трубка Удачная } \\
\hline $216-230$ & $Э_{3}$ & 158403 & $-0,4$ & 0,1 & -116 & - & $-14,5$ & 0,1 & 0,00965 & 0,70909 & $\begin{array}{c}0,0000 \\
3\end{array}$ \\
\hline $216-280$ & $Э_{3}$ & 185343 & $-9,6$ & 0,0 & -109 & - & $-13,5$ & 0,1 & 0,01044 & 0,70906 & $\begin{array}{c}0,0000 \\
3\end{array}$ \\
\hline $211-200$ & $Э_{3}$ & 102914 & $-15,9$ & 0,1 & -132 & - & $-15,7$ & 0,4 & 0,01051 & 0,70857 & $\begin{array}{c}0,0000 \\
5\end{array}$ \\
\hline $211-250$ & $Э_{3}$ & 192863 & $-17,7$ & 0,1 & -103 & - & $-11,1$ & 0,5 & 0,01664 & 0,70862 & $\begin{array}{c}0,0000 \\
4 \\
\end{array}$ \\
\hline ДС-465 & $Э_{2}$ & 372634 & 3,7 & 0,2 & -53 & 0,9 & $-9,7$ & 0,2 & 0,02889 & 0,70864 & $\begin{array}{c}0,0000 \\
3 \\
\end{array}$ \\
\hline УПП-7 & $Э_{2}$ & 196674 & $-5,3$ & 0,0 & -104 & 1,7 & $-11,5$ & 0,2 & 0,02478 & 0,70856 & $\begin{array}{c}0,0000 \\
4\end{array}$ \\
\hline $5-465$ & $Э_{2}$ & 391280 & 12,7 & 0,1 & -38 & 1,6 & $-10,7$ & 0,8 & 0,02795 & 0,70926 & $\begin{array}{c}0,0000 \\
5 \\
\end{array}$ \\
\hline \multicolumn{12}{|c|}{ Юг и запад Сибирской платформы } \\
\hline 504 & $\mathrm{~V}-Э$ & 430277 & $-31,0$ & 0,1 & -48 & - & $-8,4$ & 0,4 & 0,01874 & 0,70813 & $\begin{array}{c}0,0000 \\
3 \\
\end{array}$ \\
\hline 172 & $\mathrm{~V}$ & 363909 & 4,6 & 0,1 & -47 & - & $-11,3$ & 0,3 & 0,01059 & 0,71440 & $\begin{array}{c}0,0000 \\
7\end{array}$ \\
\hline 364 & $\mathrm{~V}$ & 369655 & $-10,0$ & 0,0 & -44 & - & $-10,6$ & 0,1 & - & - & - \\
\hline 412 & V & 374218 & 4,4 & 0,0 & -41 & - & $-12,4$ & 0,1 & 0,00737 & 0,71222 & $\begin{array}{c}0,0000 \\
5\end{array}$ \\
\hline 578 & V & 343978 & 4,4 & 0,1 & -77 & - & $-12,6$ & 0,1 & 0,00804 & 0,71014 & $\begin{array}{c}0,0000 \\
4 \\
\end{array}$ \\
\hline 585 & $\mathrm{~V}$ & 361613 & $-7,6$ & 0,1 & -133 & - & $-17,0$ & 0,0 & - & - & - \\
\hline 586 & $\mathrm{~V}$ & 379249 & 6,3 & 0,1 & -34 & - & $-11,5$ & 0,0 & - & - & - \\
\hline 670 & $\mathrm{~V}$ & 353937 & $-7,4$ & 0,1 & -56 & - & $-10,2$ & 0,1 & - & - & - \\
\hline 675 & $\mathrm{~V}$ & 335859 & $-22,5$ & 0,0 & -59 & - & $-9,7$ & 0,1 & - & - & - \\
\hline 727 & V & 359911 & $-15,2$ & 0,0 & -52 & - & $-10,1$ & 0,2 & 0,01349 & 0,70955 & $\begin{array}{c}0,0000 \\
3\end{array}$ \\
\hline 116-13 & $\mathrm{R}_{2}$ & 327872 & $-24,1$ & 0,1 & -17 & 1,7 & $-2,5$ & 0,4 & 0,01497 & 0,71985 & $\begin{array}{c}0,0000 \\
3 \\
\end{array}$ \\
\hline 133-16 & $\mathrm{R}_{2}$ & 329786 & $-22,2$ & 0,2 & -20 & 0,7 & $-2,5$ & 0,4 & 0,01520 & 0,71984 & $\begin{array}{c}0,0000 \\
2\end{array}$ \\
\hline
\end{tabular}


Примечание: «-» - не определялось. 


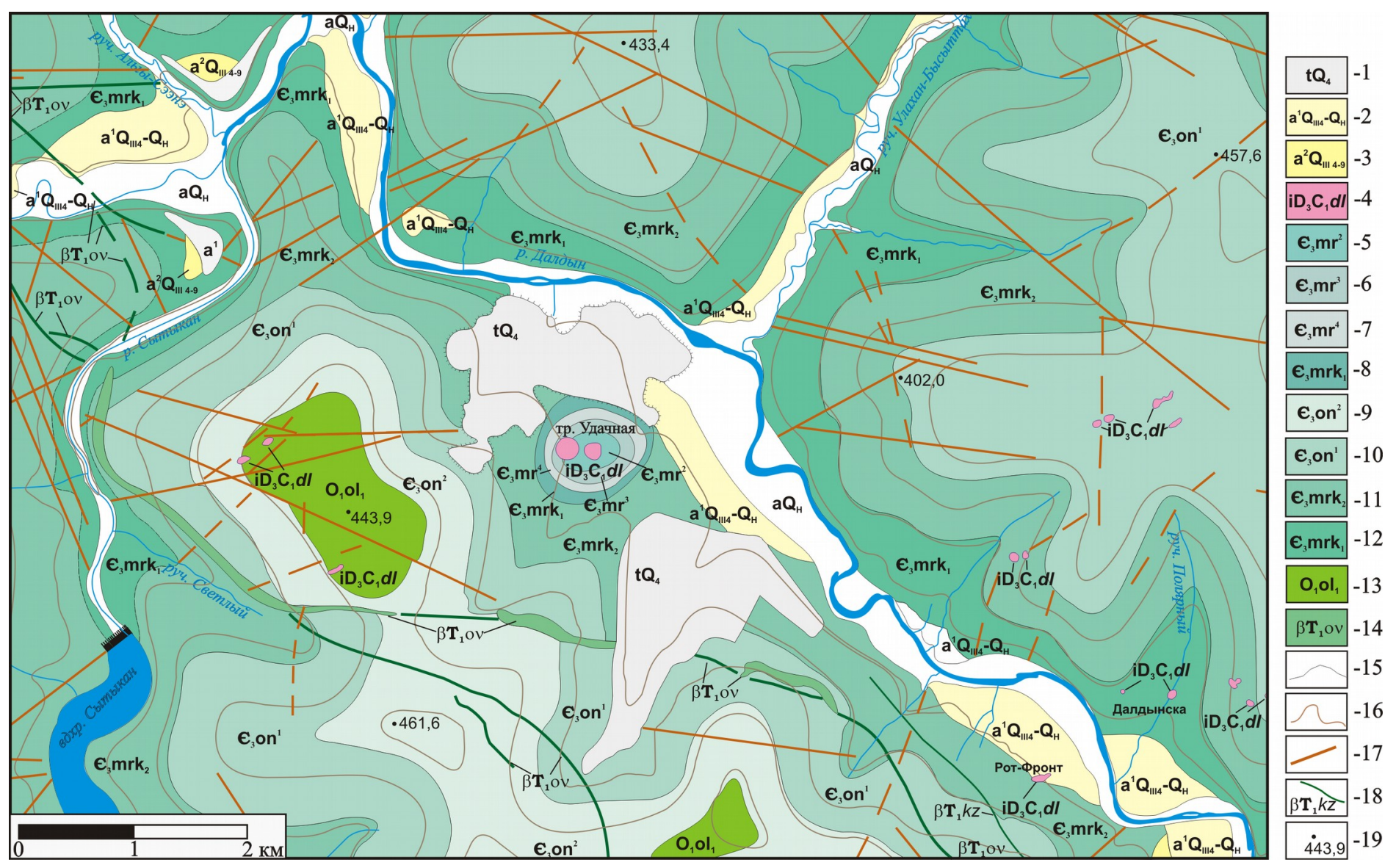




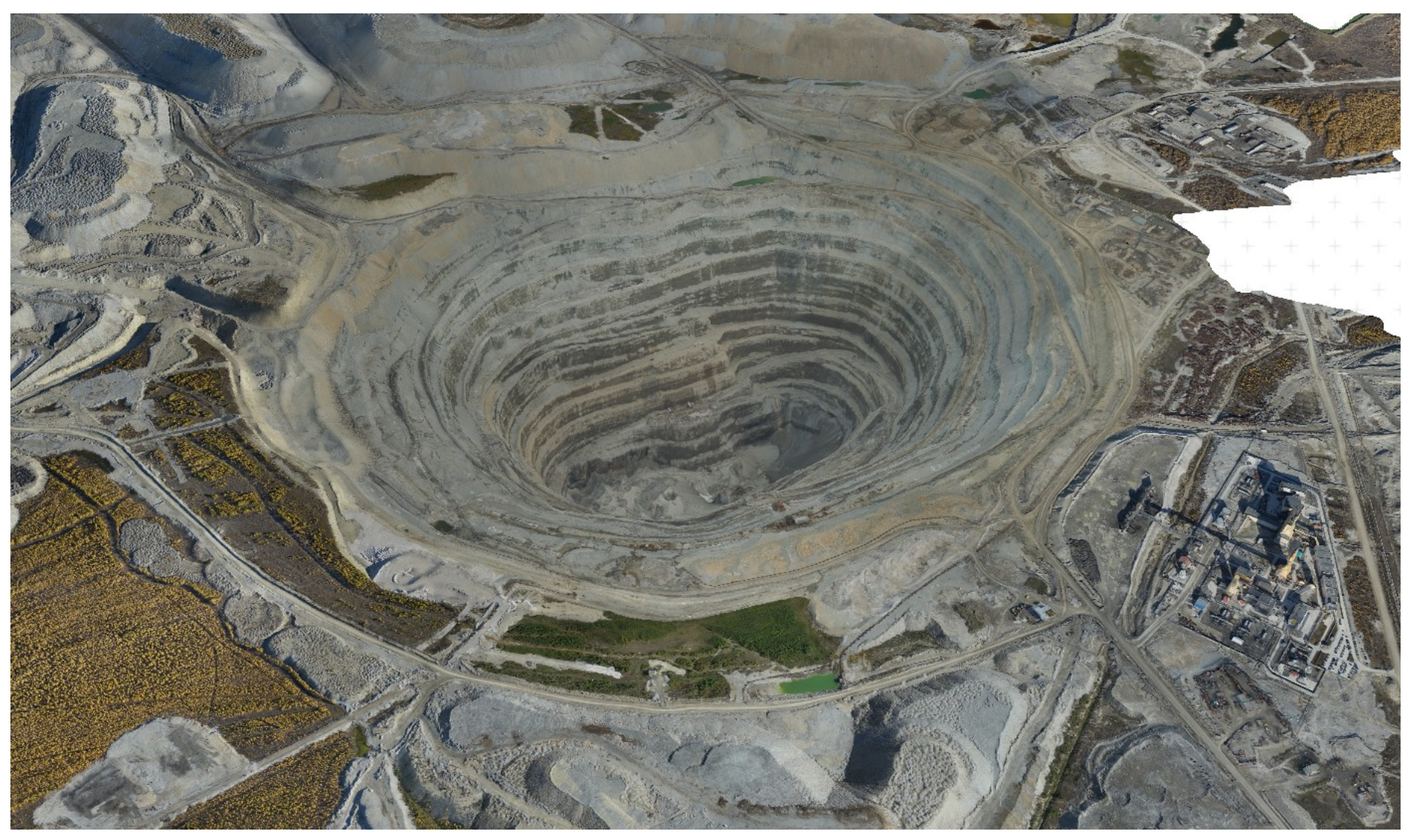




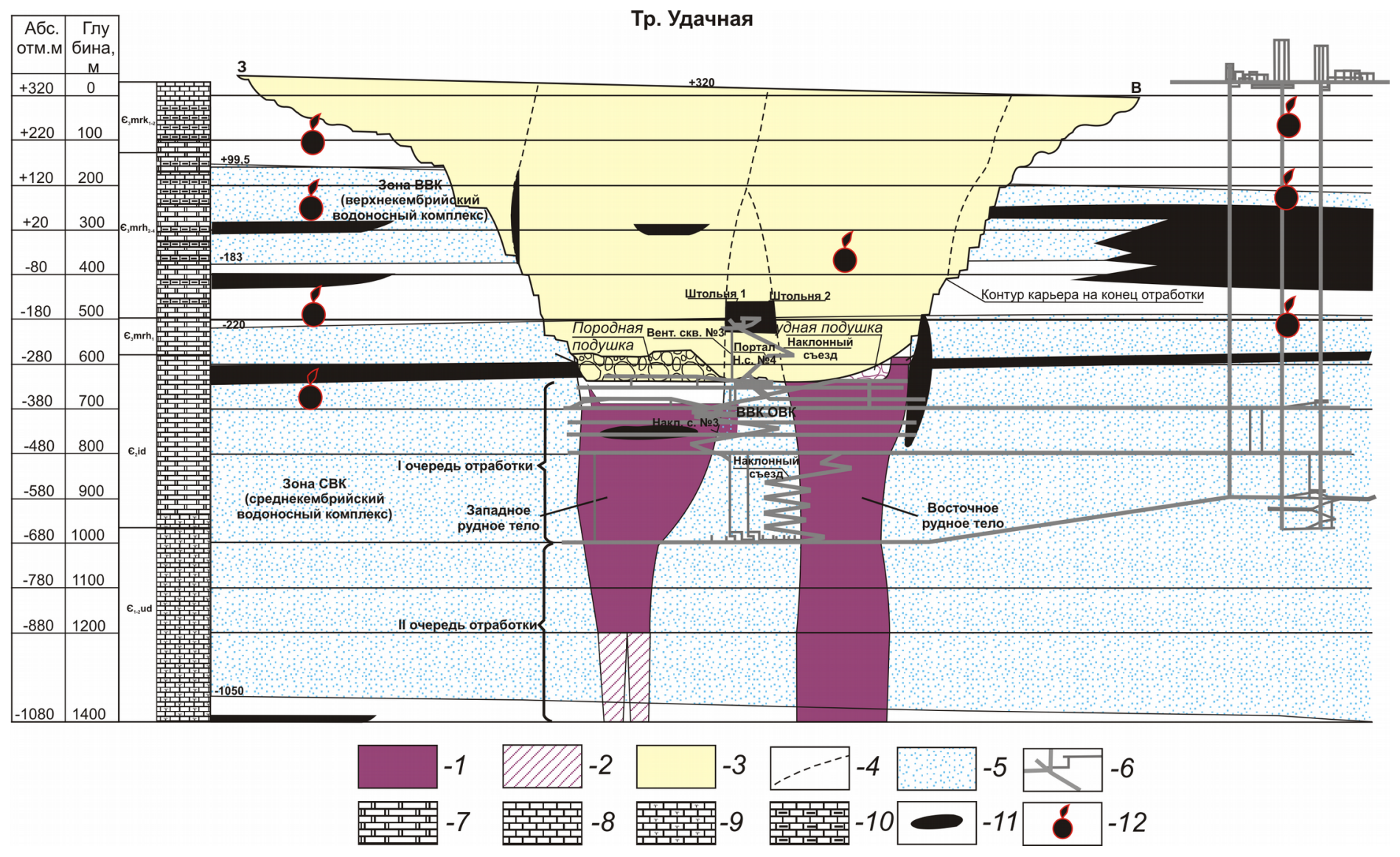



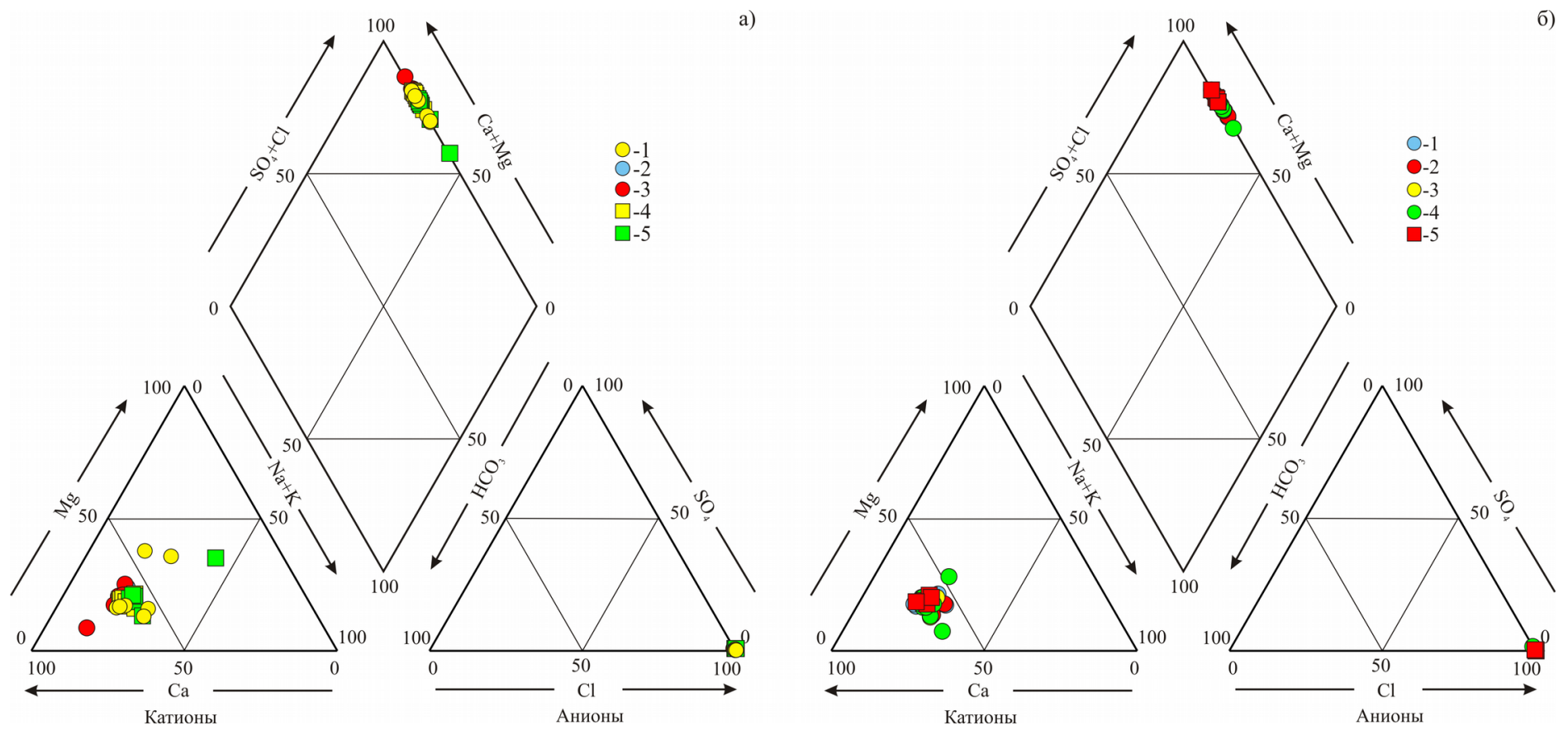


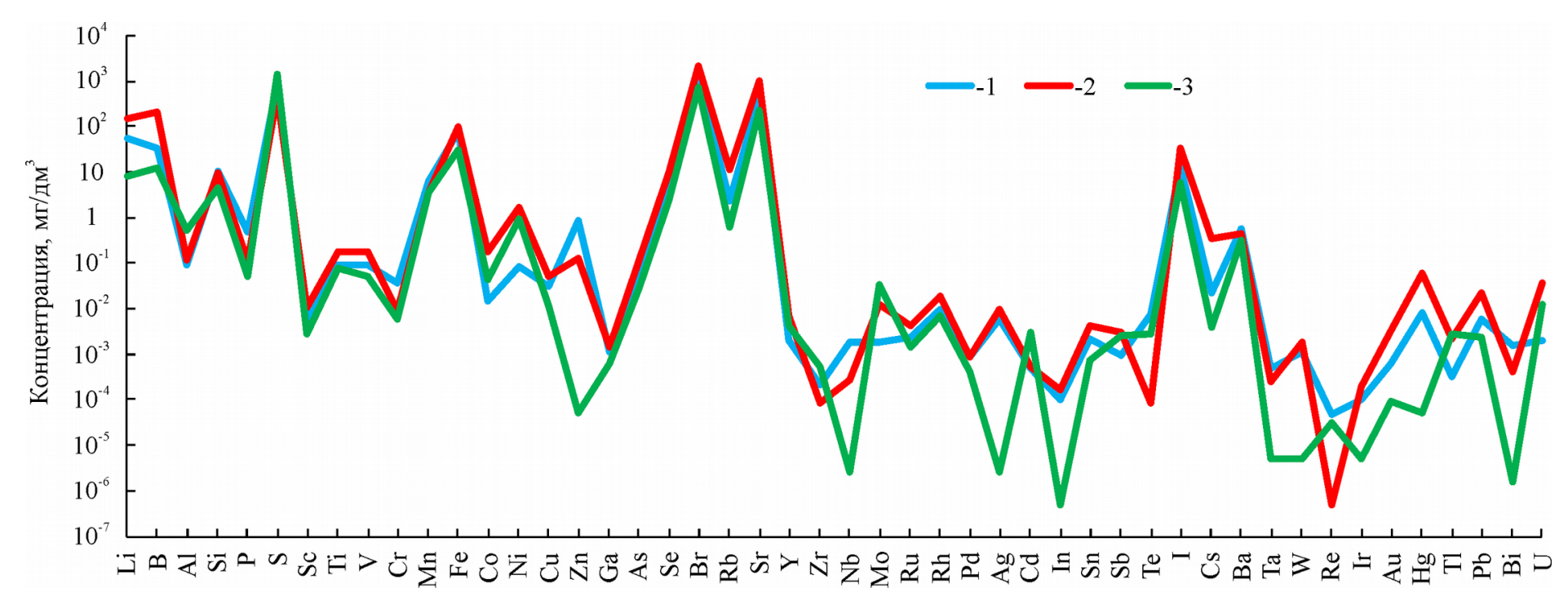



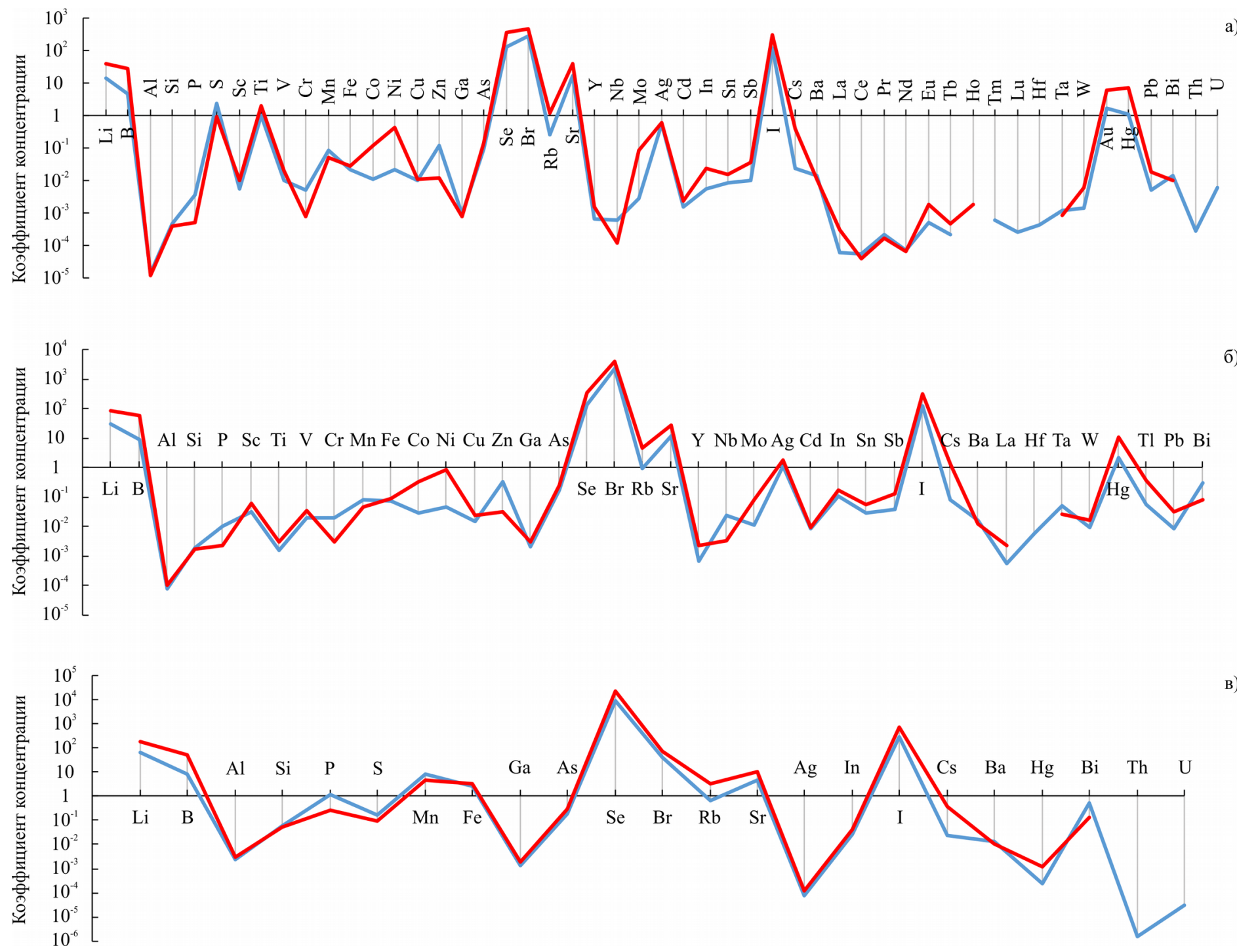

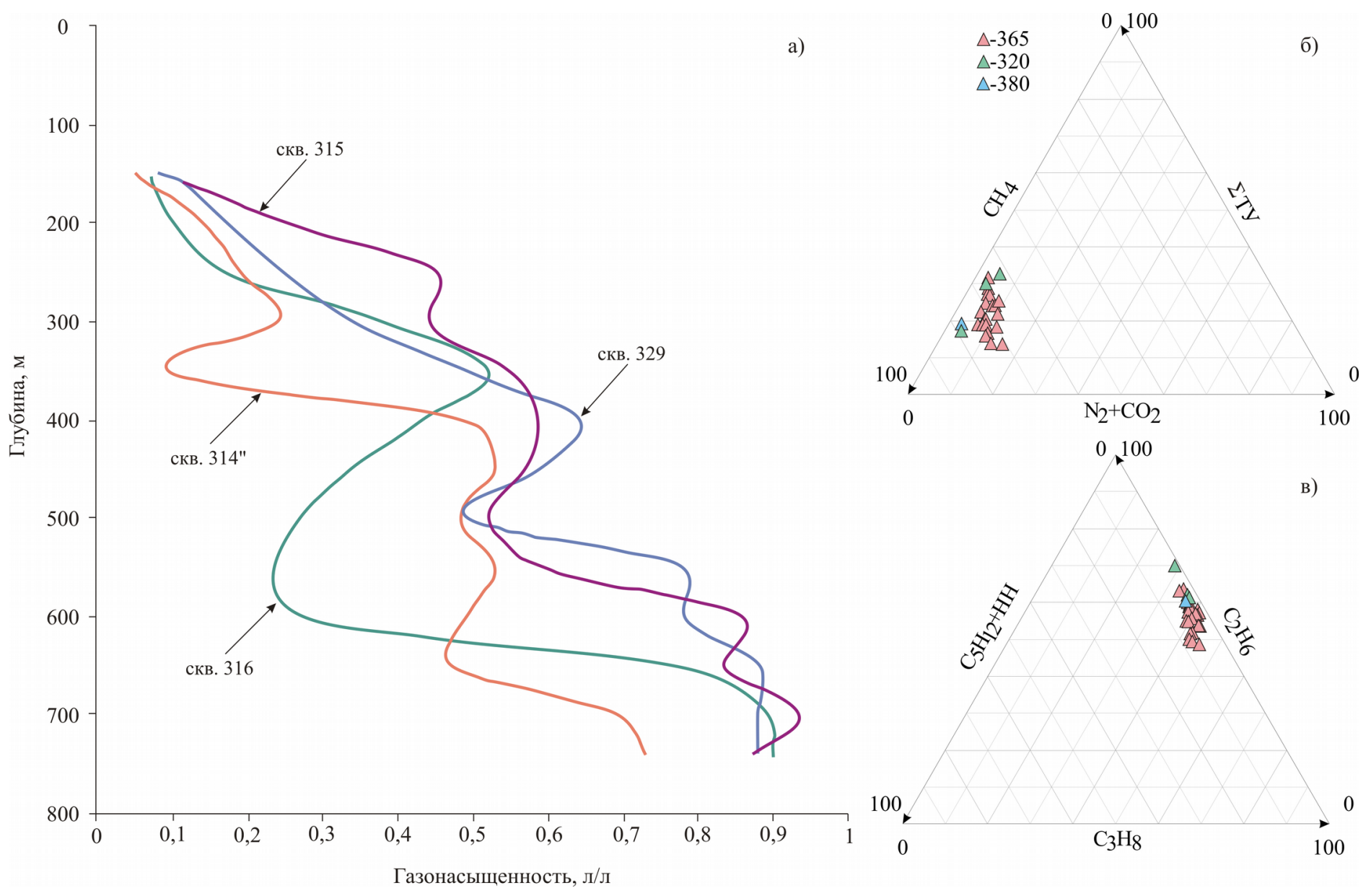


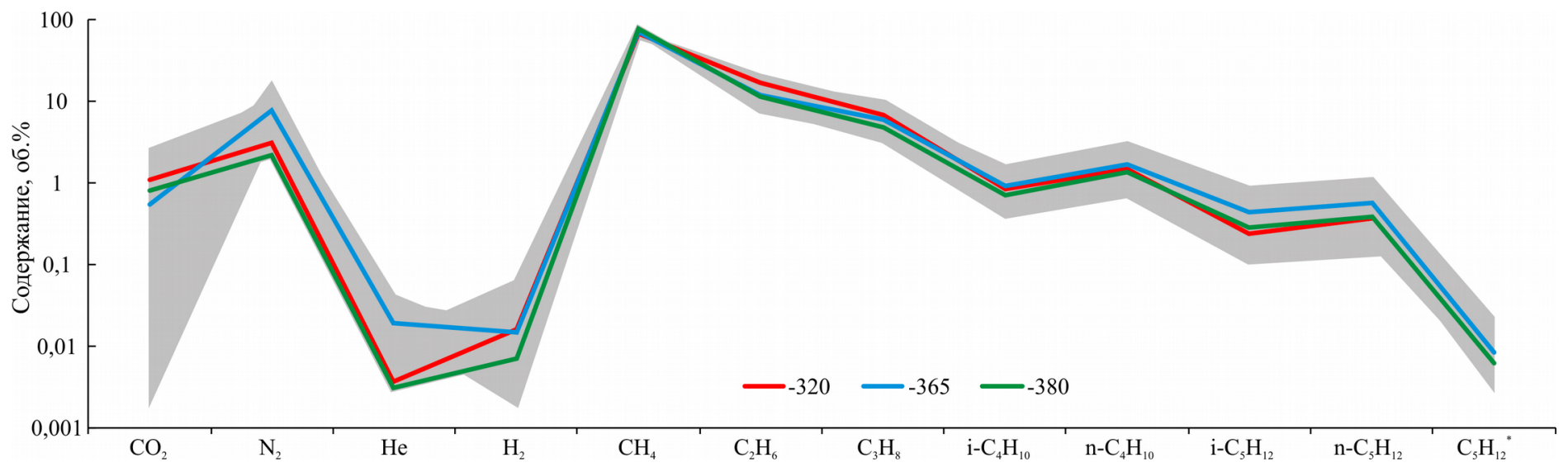



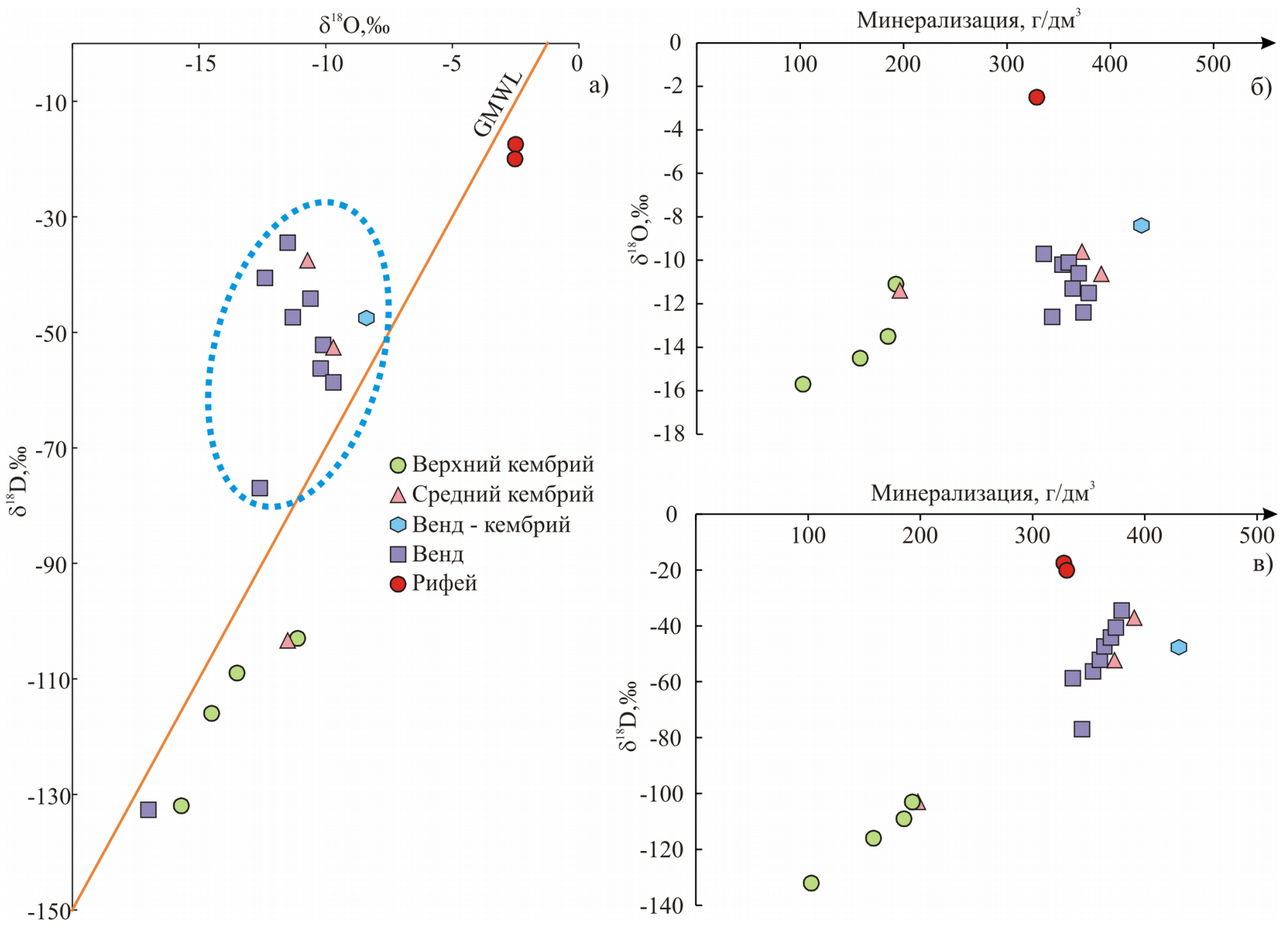


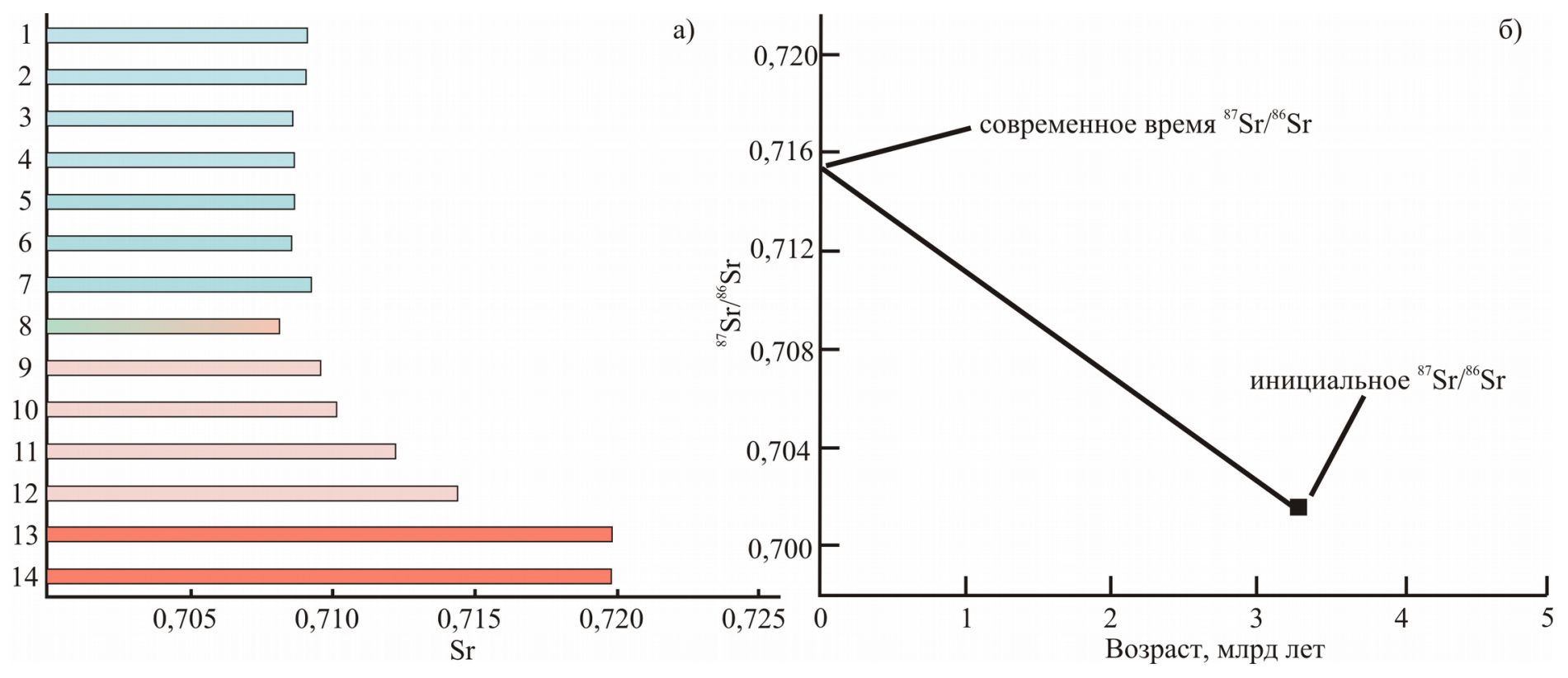



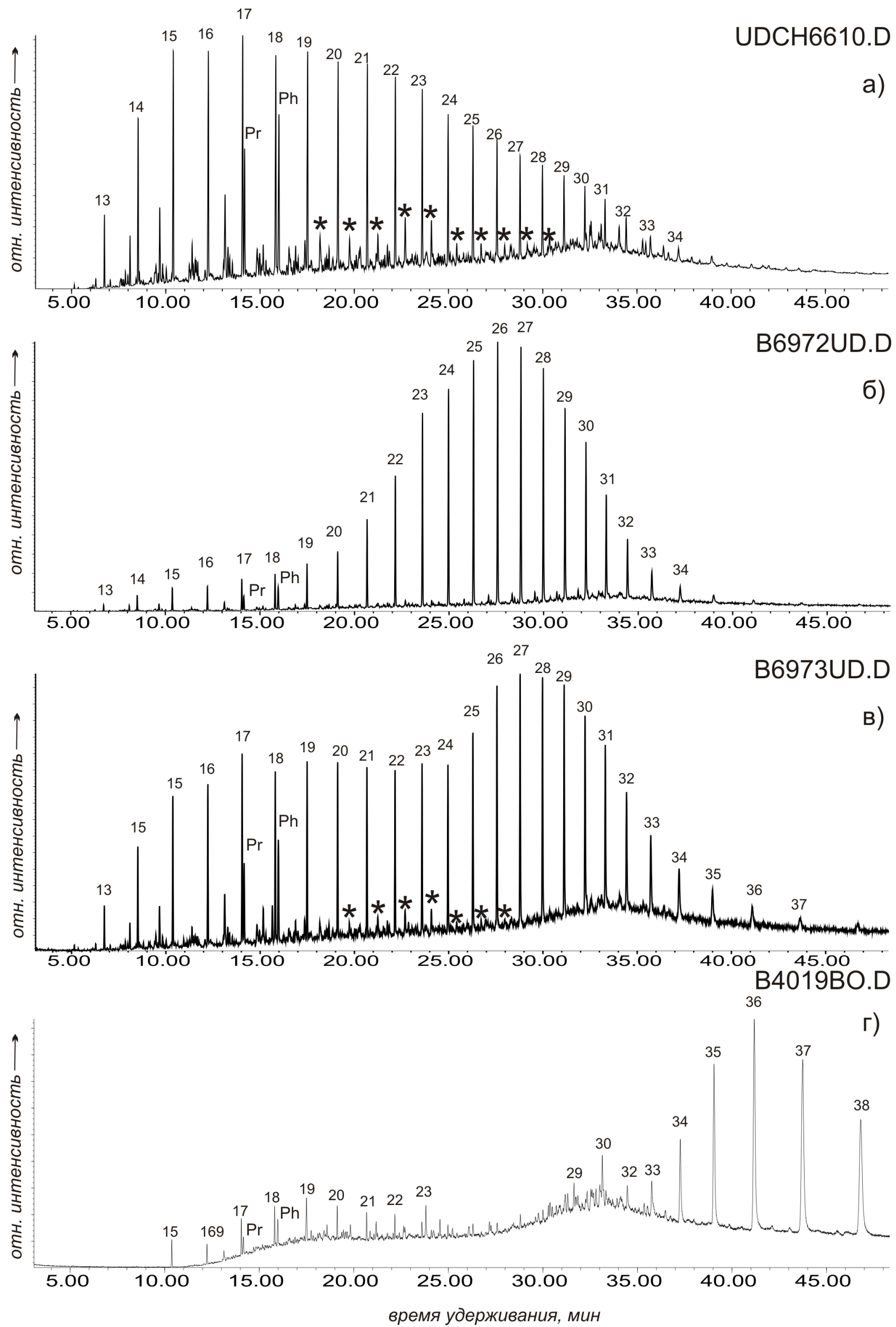

Pr - пристан

$\mathrm{Ph}$ - фитан * *12 и 13 монометилалканы 

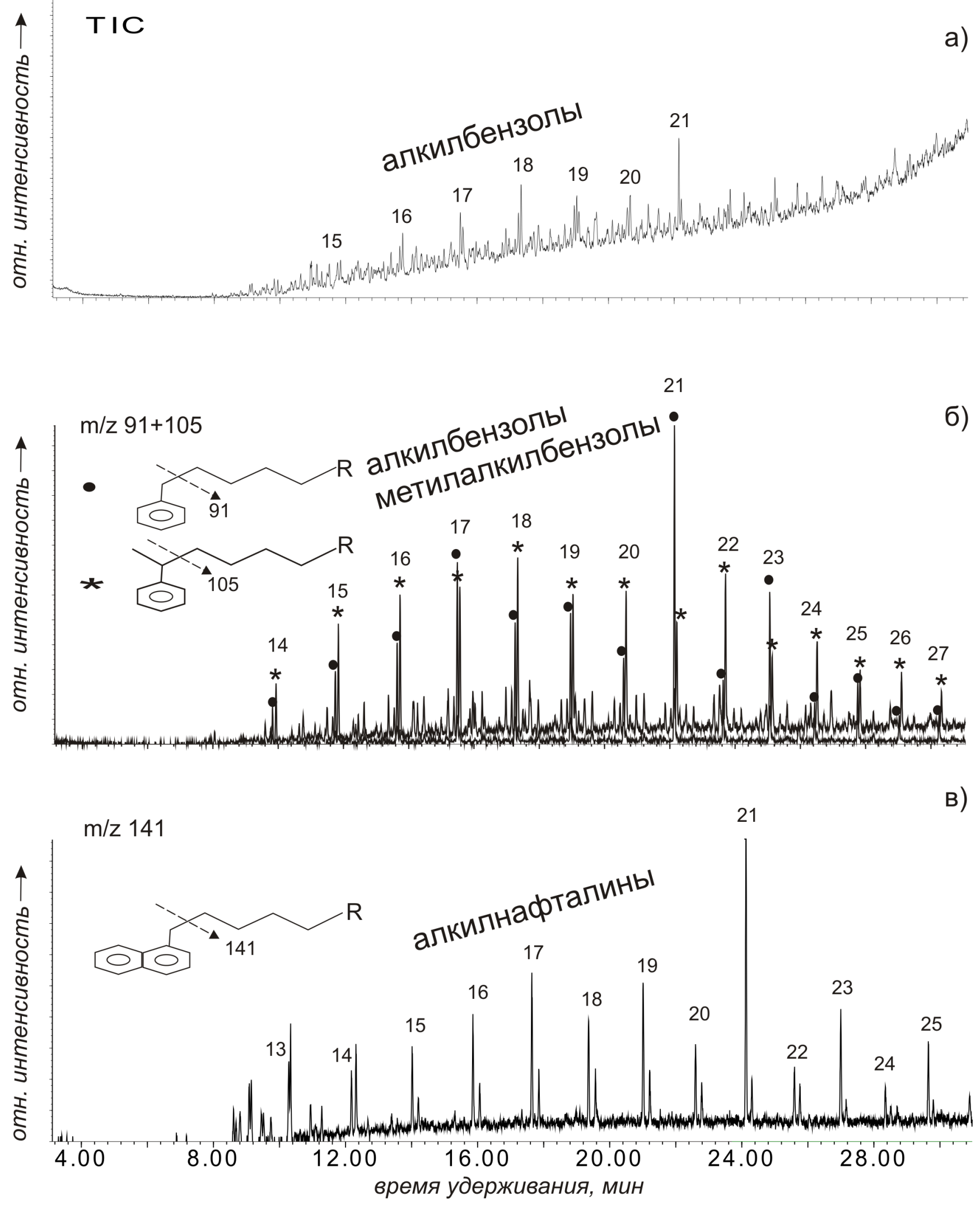


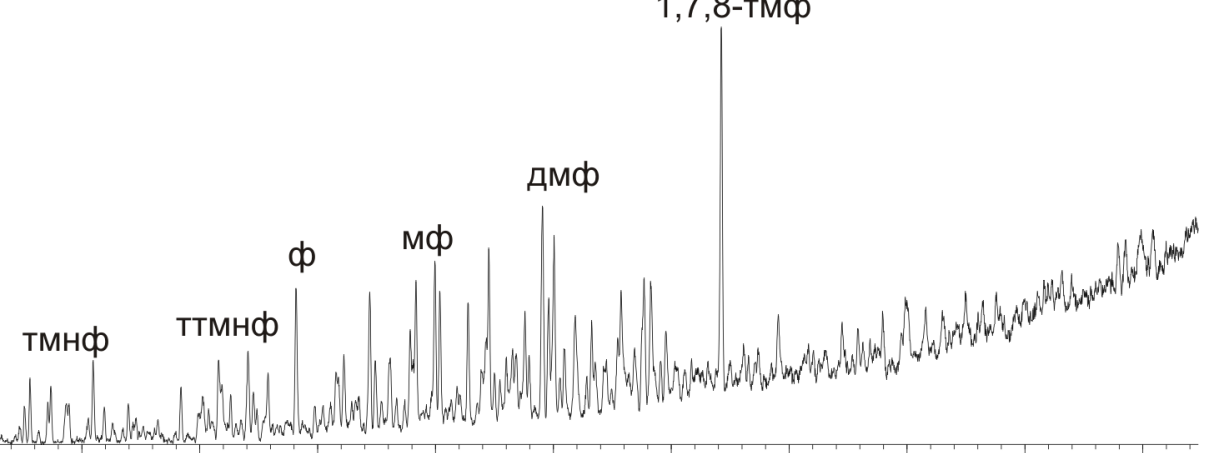

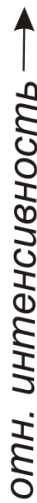

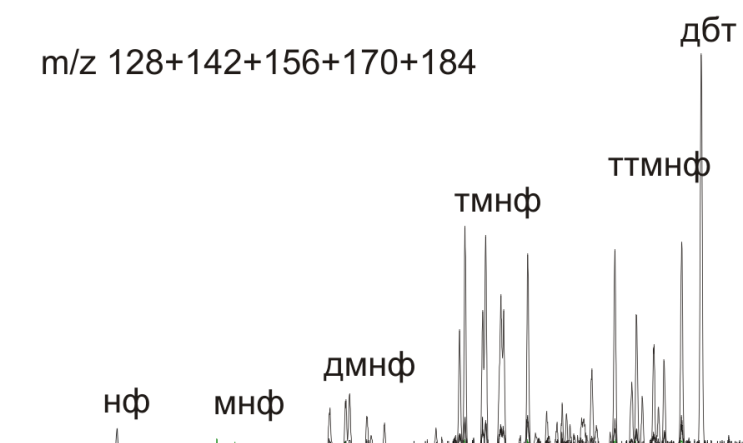

б)

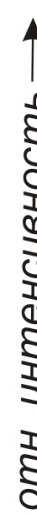

$\mathrm{m} / \mathrm{z} 184+198+212+248$

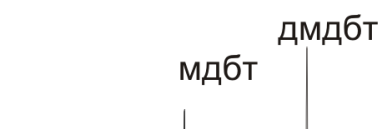

B)

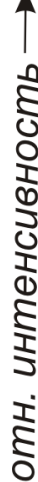

$\mathrm{m} / \mathrm{z} 178+192+206+220$

क

г)

7,8-тмф

дбт

TMHсp
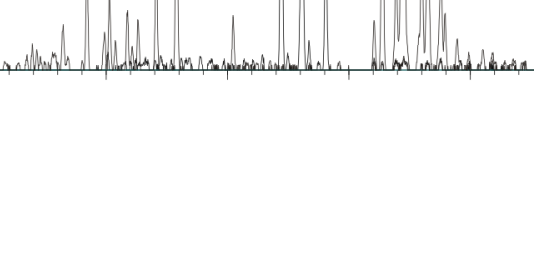

|

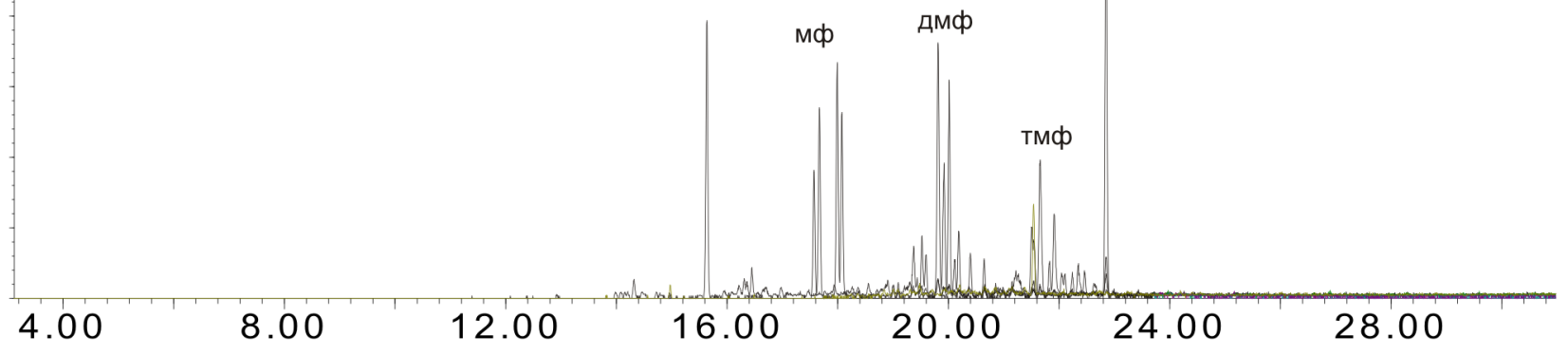

время удерживания, мин

нф - нафталин; мнф - метилнафталины; дмнф - диметилнафталины; тмнф - триметилнафтталины; ттмнф - тетраметилнафталины; дбт - дибензтиофен; мдбт - метилдибензтиофены; дмдбт - диметилбензтиофены; мбнт - метилбензонафртотиофены; ф - френантрен; мф - метилфенантрены; дмф - диметилфенантрены; тмф - триметилфенантрены; 